\title{
Effects of incremental amounts of extruded linseed on the milk fatty acid composition of dairy cows receiving hay or corn silage
}

\author{
A. Ferlay, ${ }^{1}$ M. Doreau, C. Martin, and Y. Chilliard \\ INRA, UMRH 1213 Herbivores, F-63122 Saint-Genès-Champanelle, France, VetAgro Sup, UMR Herbivores, \\ BP 10448 F-63000 Clermont-Ferrand, France
}

\begin{abstract}
The effect of supplementation of increasing amounts of extruded linseed in diets based on hay $(\mathrm{H}$; experiment 1) or corn silage (CS; experiment 2) was investigated in regard to dairy performance and the milk fatty acid (FA) composition. In each experiment, 4 lactating multiparous Holstein cows were used in a 4 $\times 4$ Latin square design (28-d periods). The cows were fed a diet (50:50 and 40:60 concentrate:forage ratio for experiments 1 and 2, respectively; dry matter basis) without supplementation (H0 or CS0) or supplemented with $5 \%$ (H5 or CS5), $10 \%$ (H10 or CS10), or 15\% (H15 or CS15) of extruded linseed. Regardless of the forage type, diet supplementation with increasing amounts of extruded linseed had no effect on the dry matter intake, milk yield, or protein content or yield. In contrast, the milk fat content decreased progressively from $\mathrm{H} 0$ to $\mathrm{H} 10$ diets, and then decreased strongly with the H15 diet in response to increasing amounts of extruded linseed. For CS diets, the milk fat content initially decreased from CS0 to CS10, but then increased with the CS15 diet. For the $\mathrm{H}$ diets, the milk saturated FA decreased $(-24.1 \mathrm{~g} / 100 \mathrm{~g}$ of FA) linearly with increasing amounts of extruded linseed, whereas the milk monounsaturated FA $(+19.0 \mathrm{~g} / 100 \mathrm{~g})$, polyunsaturated FA $(+4.9 \mathrm{~g} / 100 \mathrm{~g})$, and total trans FA $(+14.7 \mathrm{~g} / 100$ g) increased linearly. For the CS diets, the extent of the changes in the milk FA composition was generally lower than for the $\mathrm{H}$ diets. Milk 12:0 to 16:0 decreased in a similar manner in the 2 experiments with increasing amounts of extruded linseed intake, whereas 18:0 and cis-9 18:1 increased. The response of total trans 18:1 was slightly higher for the CS than $\mathrm{H}$ diets. The milk trans-10 18:1 content increased more with the CS than the $\mathrm{H}$ diets. The milk cis-9,trans-11 conjugated linoleic acid response to increasing amounts of extruded linseed intake was linear and curvilinear for the $\mathrm{H}$ diets,
\end{abstract}

Received January 9, 2013.

Accepted July 4, 2013.

${ }^{1}$ Corresponding author: anne.ferlay@clermont.inra.fr whereas it was only linear for the CS diets. The milk 18:3n-3 percentage increased in a similar logarithmic manner in the 2 experiments. It was concluded that the milk FA composition can be altered by extruded linseed supplementation with increasing concentrations of potentially health-beneficial FA (i.e., oleic acid, 18:3n-3, cis-9,trans-11 conjugated linoleic acid, and odd- and branched-chain FA) and decreasing concentrations of saturated FA. Extruded linseed supplementation increased the milk trans FA percentage.

Key words: milk n-3 fatty acid, dairy cow, extruded linseed, hay or corn silage

\section{INTRODUCTION}

Bovine milk contains a variety of FA, some of which may be of potential benefit to human health, including PUFA in the n-3 FA group and the conjugated linoleic acid (CLA) isomer cis-9,trans-11 CLA. The main n-3 FA in milk fat is linolenic acid (18:3n-3), and lower amounts of docosahexaenoic acid (22:6n-3) and eicosapentaenoic acid (20:5n-3) are also present. The 18:3n-3 FA lowers serum low-density lipoprotein cholesterol, contributing to a decrease in the incidence of human cardiovascular disease (CVD) risk (Shingfield et al., 2008). The cis-9,trans-11 isomer of CLA inhibits the growth of several human cancer cell lines, reduces the rate of chemically induced tumor development, alters lipoprotein metabolism, and modifies immune function in animal models (Shingfield et al., 2008). Thus, cis-9,trans-11 CLA may have several potential benefits in humans. Furthermore, milk is the major source of odd- and branched-chain FA (OBCFA), which exhibit anticarcinogenic properties (Shingfield et al., 2008).

In contrast, evidence exists that dietary SFA increase the concentrations of low-density lipoprotein cholesterol (Givens, 2010). Moreover, high intakes of trans FA have been associated with a substantially increased risk of CVD. Nevertheless, few studies have directly compared the effects of the trans FA from milk and industrial sources on CVD risk factors in healthy humans (review by Givens, 2010). Chardigny et al. (2008) reported that industrial trans FA lowered high-density lipoprotein 
(HDL) cholesterol compared with ruminant trans FA. Moreover, Motard-Bélanger et al. (2008) noted that moderate intake (1.5\% of energy intake) of trans FA from butter had neutral effects on plasma lipids compared with a high intake (3.6\% of energy intake) of trans FA from butter. However, intake of butter rich in trans-10 18:1 increased aortic fatty streak in rabbits compared with butter rich in trans-11 18:1 (Roy et al., 2007).

The dairy cow diet offers a way to rapidly modulate the milk FA composition to enhance beneficial FA and the highest variations can be obtained by adding oilseed supplements to the diet (Chilliard et al., 2007; Glasser et al., 2008). Linseed is the only common oilseed that provides very high levels of 18:3n-3 (Petit, 2010) and cow diets supplemented with linseed resulted in an increase in the milk 18:3n-3 concentration (Chilliard et al., 2007; Petit, 2010; Doreau et al., 2011). However, no clear relationship can be established between cow performance, milk FA composition, and the amounts of linseed fed because only a few dose-response studies have reported the effect of dietary linseed (Kennelly and Khorasani, 1992; Deaville et al., 2004; Hurtaud et al., 2010). These previous studies reported the effect of increasing doses of processed linseed (from 7 to $21 \%$ of DMI) with grass silage diets (Deaville et al., 2004), whole linseed (from 5 to $15 \%$ ) with grass silage diets (Kennelly and Khorasani, 1992) or extruded linseed (2 and 4\%) with corn silage (CS) diets (Hurtaud et al., 2010). In these studies, the range of linseed increase (from 2 to $4 \%$ seeds in DMI) was low, the experimental design did not include a control diet, or the milk FA composition was not sufficiently detailed to characterize precisely the effects of linseed on the milk FA profile. Moreover, although strong interactions have been noted between the forage type and linseed oil feeding (Chilliard and Ferlay, 2004), to our knowledge, no research has been published comparing the effects of extruded linseed supplementation when added to different types of forages. Thus, our aim was to analyze the effects of increasing dietary concentrations of extruded linseed, from 0 to $15 \%$ of DMI, added to either hay $(\mathbf{H})$ - or CS-based diets on dairy cow performance and the milk FA composition performed on 2 successive experiments.

\section{MATERIALS AND METHODS}

Two experiments were performed during 2 successive years using a protocol approved by the Animal Care Committee of Institut National de la Recherche Agronomique (INRA; Clermont-Ferrand, France). All procedures were conducted in accordance with French guidelines for the use of experimental animals and com- pliant with animal welfare and good practice (Veissier, 1999).

\section{Animals, Experimental Design, and Diets}

Experiment 1. To allow the cows to adapt to natural grassland H-based diets, 4 lactating multiparous Holstein cows were fed a diet rich in natural grassland $\mathrm{H}$ for $3 \mathrm{wk}$ before the first experimental period. These lactating cows (117 $\pm 26 \mathrm{DIM}, 655 \mathrm{~kg}$ of BW) cannulated at the rumen and duodenum were used in a $4 \times 4$ Latin square design during four 4 -wk periods to evaluate the responses to diets with a 50:50 concentrate:forage ratio supplemented (on a DM basis) with 0 (H0), 7, 14, or $21 \%$ extruded linseed mixture (extruded mixture of linseed:wheat bran, 70:30; Valorex, Combourtillé, France) so that the extruded linseed represented 5 (H5), $10(\mathbf{H 1 0})$, and 15\% (H15) of the dietary DMI, respectively. The control concentrate contained linseed meal, wheat bran, and corn grain, which were substituted for the supplemented diets, in part, with the extruded linseed mixture. The concentrate mixture was homogeneously blended with the extruded linseed and other cereals and meal, and the mixture was prepared daily. Portions of 60 and $40 \%$ of the daily amount were offered at 0900 and $1630 \mathrm{~h}$, respectively; $\mathrm{H}$ was offered in equal amounts at 0900, 1330, and $1630 \mathrm{~h}$.

Experiment 2. The same experimental design as that in experiment 1 was used. Four lactating multiparous Holstein cows were adapted to a CS-based diet during the 3 wk before the experiment. The cows $(96 \pm$ 29 DIM, $668 \mathrm{~kg}$ of BW) cannulated at the rumen and the duodenum were used in a $4 \times 4$ Latin square design during four 4 -wk periods to evaluate the responses to diets with a 40:60 concentrate:forage ratio (CS forage plus $1 \mathrm{~kg}$ of natural grassland $\mathrm{H}$ ) supplemented (on a DM basis) with 0 (CS0), 7, 14, or $21 \%$ extruded linseed mixture (extruded mixture of linseed:wheat bran, 70:30; Valorex) so that the extruded linseed represented 5 (CS5), 10 (CS10), or 15\% (CS15) of dietary DMI, respectively. The control concentrate contained linseed meal, soybean meal, wheat bran, and corn grain, which were substituted for the supplemented diets, in part, with the extruded linseed mixture. The concentrate mixture was homogeneously blended with the extruded linseed and other cereals and meal. The mixture was prepared daily and was offered in 2 amounts (60 and $40 \%$ ) at 0900 and $1630 \mathrm{~h}$, respectively. Hay and CS were offered in equal amounts at 0900 and $1630 \mathrm{~h}$.

For the 2 experiments, the desired concentrate:forage ratio was obtained by the daily adjustment of the forage and concentrate amounts offered, depending on the refusals of the previous day and being greater than 
those ingested previously. The diets were formulated in an attempt to cover $105 \%$ of the INRA energy and protein requirements for maintenance and lactation (INRA, 2007). The first $5 \mathrm{~d}$ of each experimental period were used as a transition between the treatments. The cows were housed in a tie-stall barn during the experiment and were milked at 0600 and $1700 \mathrm{~h}$.

\section{Sampling, Measurements, and Analyses}

For the 2 experiments, samples of all the forages, concentrates, and feed refusals were collected daily during wk 4 of each experimental period, and the feed samples obtained during this week were pooled to provide 1 sample per period and stored at $-20^{\circ} \mathrm{C}$. The feed DM concentration was determined after drying at $103^{\circ} \mathrm{C}$ for $24 \mathrm{~h}$. Samples of all feedstuffs (forages and concentrates) were lyophilized, sieved through a 1-mm screen and analyzed for OM, CP, crude fiber, starch, and ether extract using standard procedures (AOAC International, 1997), and NDF and ADF analyses according to Van Soest et al. (1991). The cow BW was recorded at the beginning and the end of each experiment. The milk production and DMI were recorded daily throughout the experiment. The milk was sampled at each milking during the last $5 \mathrm{~d}$ of wk 4 . One $50-\mathrm{mL}$ aliquot from each of these milkings containing potassium bichromate (Merck Chimie SAS, Fontenaysous-Bois, France) was stored at $4^{\circ} \mathrm{C}$ until analyzed for the fat, protein, and lactose content and the SCC by infrared analysis (AOAC International, 1997) using a 3-channel spectrophotometer [Centre Interprofessionnel Laitier Auvergne Limousin (CILAL), Theix, France]. Additionally, 3-mL aliquots from 2 consecutive milkings on the last day of wk 4 were also collected and stored at $-20^{\circ} \mathrm{C}$ until the end of the experiment before lyophilization (Thermovac TM-20; Froilabo, Ozoir-laFerrière, France) and FA analysis. Once lyophilized, these samples were composited based on the a.m. and p.m. milk production (60:40).

The FA composition of feedstuffs was determined using ground lyophilized samples of the forages and concentrates, which were methylated as described by Sukhija and Palmquist (1988), with modifications (Loor et al., 2004). Tricosanoate (Sigma-Aldrich Chemie S.a.r.l., Saint-Quentin Fallavier, France) was used as an internal standard.

The FA in the lyophilized milk were directly methylated as described by Ferlay et al. (2010). Briefly, the lipids in the lyophilized milk samples were directly methylated using $2 \mathrm{~mL}$ of $0.5 \mathrm{M}$ sodium methoxide plus $1 \mathrm{~mL}$ of hexane at $50^{\circ} \mathrm{C}$ for $5 \mathrm{~min}$, followed by cooling with the addition of $75 \mu \mathrm{L}$ of $12 \mathrm{M} \mathrm{HCl}$ at room temperature for $10 \mathrm{~min}$. The FA methyl esters
(FAME) were recovered in $3 \mathrm{~mL}$ of hexane and washed with $3 \mathrm{~mL}$ of water. The samples were injected using an autosampler into a Trace-GC 2000 series gas chromatograph equipped with a flame ionization detector (Thermo Finnigan, Les Ulis, France). The FAME from all the samples were separated on a $100-\mathrm{m} \times 0.25-\mathrm{mm}$ i.d. fused-silica capillary column (CP-Sil 88; Chrompack, Middelburg, the Netherlands). The injector temperature was maintained at $250^{\circ} \mathrm{C}$ and the detector temperature at $255^{\circ} \mathrm{C}$. The initial oven temperature was held at $70^{\circ} \mathrm{C}$ for $1 \mathrm{~min}$, increased by $5^{\circ} \mathrm{C} / \mathrm{min}$ to $100^{\circ} \mathrm{C}$ (held for $2 \mathrm{~min}$ ), increased by $10^{\circ} \mathrm{C} / \mathrm{min}$ to $175^{\circ} \mathrm{C}$ (held for $40 \mathrm{~min}$ ), and then increased by $5^{\circ} \mathrm{C} / \mathrm{min}$ to a final temperature of $225^{\circ} \mathrm{C}$ (held for $15 \mathrm{~min}$ ). The carrier gas was hydrogen. The FAME peaks were routinely identified by a comparison of the retention times with authentic FAME standards (GLC 463, Nu-Chek Prep Inc., Elysian, MN; reference mixture 47 885, Supelco Inc., Bellefonte PA) and a mixture of C18:1, C18:2, and CLA isomers (Loor et al., 2005a). Isomers of CLA were identified using authentic CLA methyl ester standards (O5632; Sigma-Aldrich Chemie S.a.r.l.), and the elution order of the isomers reported in the literature (Shingfield et al., 2008). A reference standard butter (CRM 164; Commission of the European Communities, Community Bureau of Reference, Brussels, Belgium) was used to estimate the correction factors for the short-chain FA (4:0 to 10:0).

Blood samples were obtained on d 2 of wk 4 of each experimental period from each cow; the samples were collected before the morning feeding from the jugular and abdominal mammary veins by venipuncture using EDTA-containing $(0.47 \mathrm{~mol} / \mathrm{L})$ evacuated blood collection tubes (Elvetec Services, Meyzieu, France). The plasma was separated immediately after sampling by centrifugation at $3,000 \times g$ for $15 \mathrm{~min}$ at $4^{\circ} \mathrm{C}$. Plasma samples were frozen at $-20^{\circ} \mathrm{C}$ until analyzed for NEFA, glucose, acetate, and BHBA. The plasma glucose, NEFA, and acetate concentrations were determined spectrophotometrically using the glucose dehydrogenase method (glucose RTU kit; bioMérieux, Lyon, France), the acyl-CoA synthetase method (WakoUnipath NEFA-C kit; Oxoid SA, Dardilly, France), and the L-malate dehydrogenase/citrate synthase/acyl-CoA synthetase method (EnzyPlus, EZA811; Diffchamb SA, Lyon, France), respectively. The BHBA concentration was determined using the enzymatic method reported by Brashear and Cook (1983).

\section{Statistical Analyses}

For experiment 1, the data for 1 cow fed the H15 diet during the fourth period were excluded because of acute mastitis. For experiment 2, the data for 2 cows 
fed the CS5 diet were excluded because of subacute mastitis, the first one during the second period and the other during the fourth period.

For each experiment, the data for the DMI, milk production and composition, FA in the milk fat, and plasma metabolites are reported as least squares means \pm standard error of the mean. The data were analyzed separately for the 2 experiments as a Latin square using PROC MIXED of SAS (SAS Institute, 2003). The statistical model included factors of cow, period, diet, and residual error. The fixed effects included the period and diet, and the cow was the random effect. Compound symmetry was the covariance structure for period. Linear and quadratic contrast statements were used to test the effect of the increasing amounts of extruded linseed. Significance was declared at $P \leq 0.05$ and trends were considered at $0.05 \leq P \leq 0.10$.

Furthermore, the relationships between the milk fat content, and the selected milk FA were studied using correlation calculations (SAS Institute, 2003). To analyze the interaction between the nature of the forage and increasing amounts of extruded linseed, the data in Figures 1 and 2 (milk fat content, 18:3n-3 intake, and selected milk FA) were analyzed by multiple linear regressions (SAS Institute, 2003). For Figure 1, the model used was as follows:

Milk concentration of selected FA ( $\mathrm{g} / 100 \mathrm{~g}$ of total

$\mathrm{FA})=$ slope $1 \times$ amount intake of 18:3n-3 (g/d)

+ slope $2 \times$ nature of forage $(\mathrm{H}$ vs. $\mathrm{CS})+$ intercept 1 .

For Figure 2, the model used was as follows:

Milk fat content $(\mathrm{g} / \mathrm{kg})=$ slope $3 \times$ milk

concentration of selected FA (g/100 g of total FA)

+ slope $4 \times$ nature of forage $(\mathrm{H}$ vs. $\mathrm{CS})+$ intercept 2 .

Finally, a principal components analysis (PCA) was performed using Statistica software (StatSoft France, Maisons-Alfort, France) to evaluate the relationships between the milk percentages of 68 individual FA, milk yield, milk fat content, and yield on one hand, and the variations due to the cow and diet on the other hand.

\section{RESULTS}

\section{Intake, Milk Production, and Plasma Metabolites}

Experiment 1. By design, the extruded linseed intake increased from H0 to H15 diets (linear effect, $P$ $<0.001$ ), whereas the linseed meal, wheat bran, and corn grain intakes decreased (linear effect, $P<0.001$;
Table 1). The $\mathrm{H}$ intake decreased (quadratic effect, $P$ $<0.05)$ initially from H0 to H5 diets, and then it increased with the $\mathrm{H} 15$ diet. By design, the starch intake decreased linearly $(P<0.01)$ from H0 to H15 diets, and the ether extract and individual FA intake increased linearly $(P<0.001)$ from H0 to H15 diets. The milk, protein, and lactose yields, and the lactose content did not differ between the diets, whereas the milk fat content decreased in a quadratic manner $(P<0.05)$ from $35.9 \mathrm{~g} / \mathrm{kg}$ for H0 to $29.1 \mathrm{~g} / \mathrm{kg}$ for H15 diets, with most of the decrease occurring between $\mathrm{H} 10$ and H15 diets. The milk fat yield decreased numerically between H10 and H15 diets. The milk protein content initially decreased (quadratic effect, $P<0.05$ ) from H0 to H10 diets, and then increased with the H15 diet. The net energy balance increased linearly $(P<0.05)$ from $\mathrm{H} 5$ to $\mathrm{H} 15$ diets.

Feeding increasing amounts of extruded linseed tended $(P<0.10)$ to result in lower jugular concentrations of BHBA. The jugular-mammary venous difference for NEFA was slightly positive (linear effect, $P<0.01$ ) for $\mathrm{H0}$ and slightly negative for the other diets (Table 2).

Experiment 2. As observed for experiment 1, by design, the extruded linseed intake increased linearly $(P<0.001)$ from the CS0 to CS15 diets, whereas the linseed meal, wheat bran, and corn grain intakes decreased (linear effect, $P<0.001$; Table 3). By design, the ether extract $(P<0.001)$ and individual FA intake increased linearly from CS0 to CS15 diets, and intakes and balances of net energy and protein digestible in the intestines did not differ between the diets. Although the milk yield, protein and lactose contents, and protein and lactose yields did not differ between the diets (Table 3), the milk fat content initially decreased (quadratic effect, $P<0.05$ ) from $33.8 \mathrm{~g} / \mathrm{kg}$ for CS0 to 27.1 $\mathrm{g} / \mathrm{kg}$ for CS10 diets, but then increased with the CS15 diet $(31.2 \mathrm{~g} / \mathrm{kg})$. The milk fat yield decreased numerically from CS0 to CS10 diets.

The jugular BHBA concentration increased initially from CS0 to CS5 diets and then decreased with the CS15 diet (quadratic effect, $P<0.05$ ). The jugular acetate concentration decreased with increasing amounts of extruded linseed (linear contrast, $P<0.05$ ).

The jugular-mammary venous difference for acetate decreased between CS5 and CS10 diets (linear effect, $P<0.05)$. The jugular-mammary venous difference for BHBA tended (linear effect, $P<0.10$ ) to be lower with the CS15 compared with the CS10 diet (Table 4).

\section{Milk FA Composition}

Experiment 1. The milk FA composition was strongly influenced by increasing amounts of extruded linseed in the diet (Table 5). The milk SFA decreased 
a)

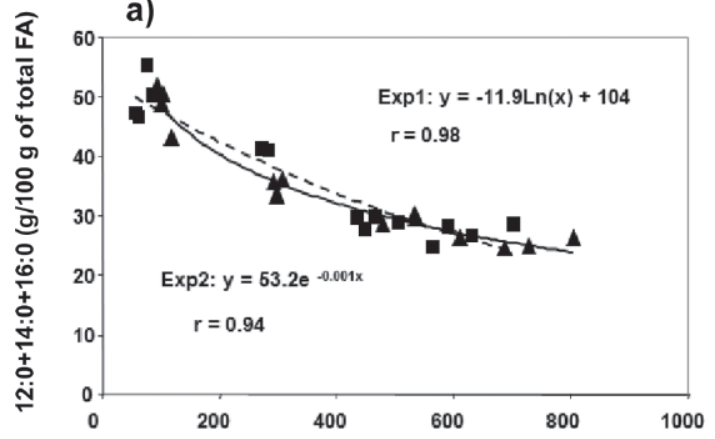

c)

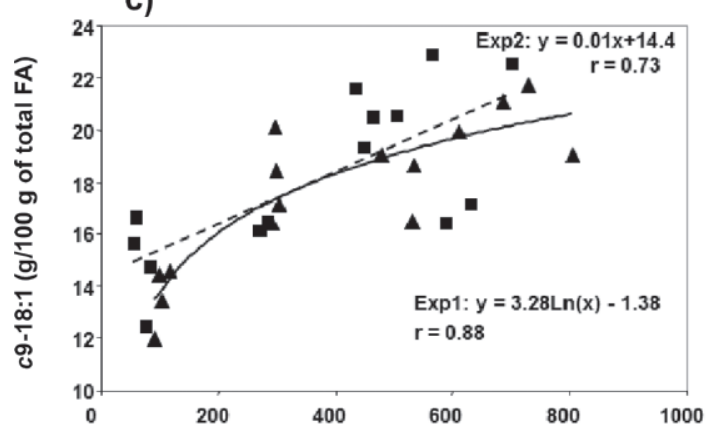

e)

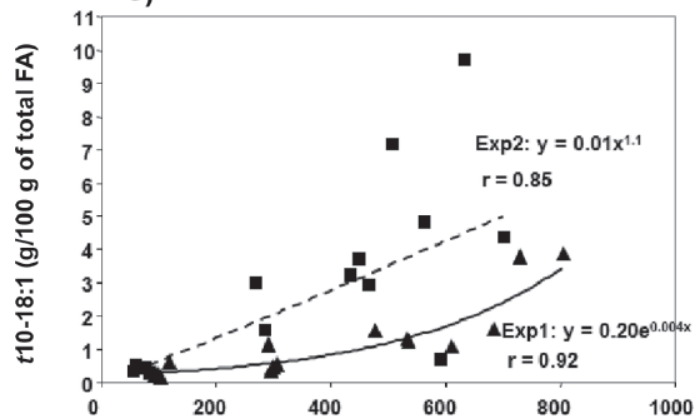

g)

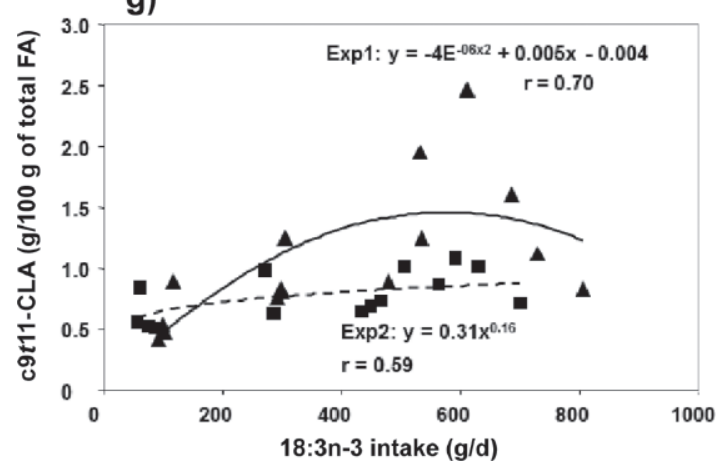

b)

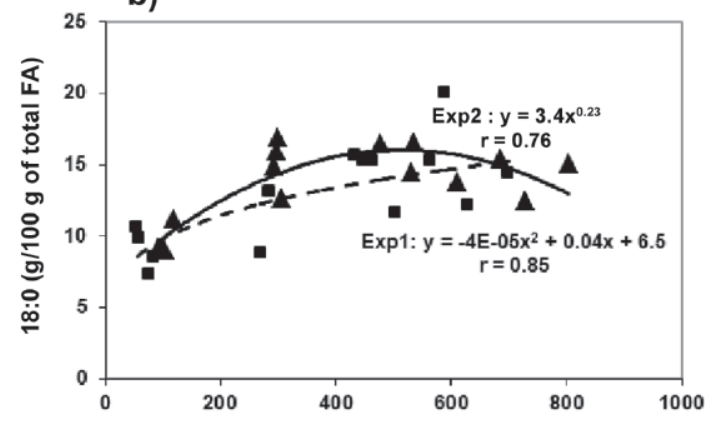

d)

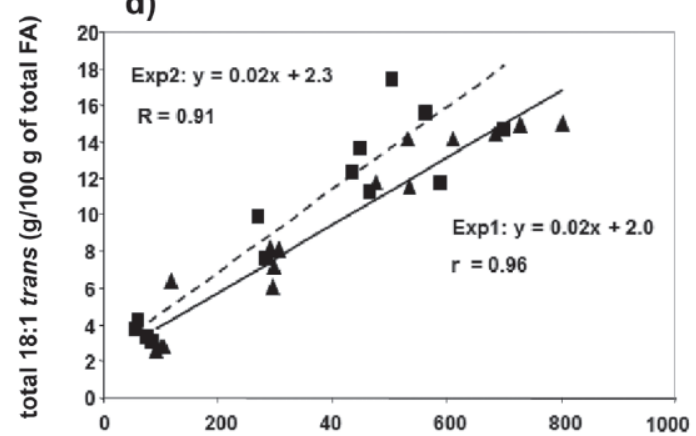

f)

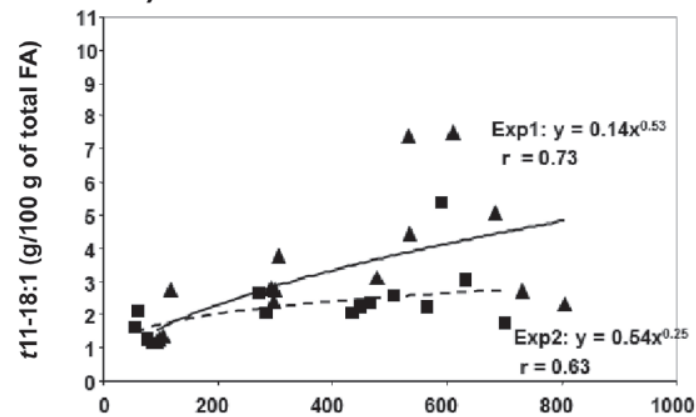

h)

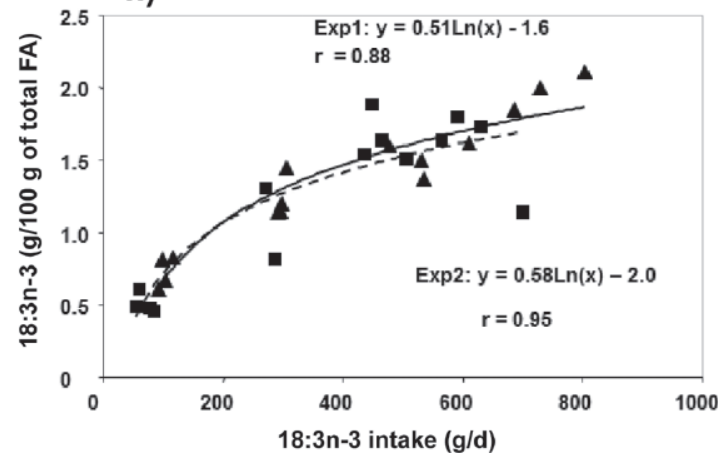

Figure 1. Relationships between 18:3n-3 intake and selected FA percentages in milks from Holstein cows fed natural grassland hay- [triangles and solid line; experiment 1 (Exp1); $\mathrm{n}=15$ ] or corn silage-based [squares and dashed line; experiment 2 (Exp2); $\mathrm{n}=14$ ] diets without supplemental extruded linseed or supplemented with extruded linseed at 5, 10, or 15\% of DM. The selected milk FA can also be predicted by a linear combination of 18:3n-3 intake (x; g/100 g of total FA) and nature of forage (z; hay forage considered as 0 ). Regression curves within experiment were represented when $P<0.05$. (a) y $=-0.04 \mathrm{x}(P<0.001)+0.17 \mathrm{z}(\mathrm{NS})+50.2(P<0.001), \mathrm{r}=0.93 ;(\mathrm{b}) \mathrm{y}=0.009 \mathrm{x}(P<0.001)-0.56 \mathrm{z}$ $(\mathrm{NS})+10.6(P<0.001), \mathrm{r}=0.67 ;(\mathrm{c}) \mathrm{y}=0.01 \mathrm{x}(P<0.001)+0.87 \mathrm{z}(\mathrm{NS})+12.7(P<0.001), \mathrm{r}=0.78 ;(\mathrm{d}) \mathrm{y}=0.02 \mathrm{x}(P<0.001)+1.9 \mathrm{z}(P$ $<0.05)-0.61(\mathrm{NS}), \mathrm{r}=0.93 ;(\mathrm{e}) \mathrm{y}=0.006 \mathrm{x}(P<0.001)+2.0 \mathrm{z}(P<0.01)-3.2(P<0.01), \mathrm{r}=0.75 ;(\mathrm{f}) \mathrm{y}=0.004 \mathrm{x}(P<0.01)-0.97 \mathrm{z}(P$ $<0.10)+3.0(P<0.01), \mathrm{r}=0.59 ;(\mathrm{g}) \mathrm{y}=0.001 \mathrm{x}(P<0.01)-0.27 \mathrm{z}(P<0.10)+0.96(P<0.001), \mathrm{r}=0.61 ;(\mathrm{h}) \mathrm{y}=0.002 \mathrm{x}(P<0.001)-$ $0.06 \mathrm{z}(\mathrm{NS})+0.62(P<0.001), \mathrm{r}=0.90 . c=$ cis $t=$ trans; CLA $=$ conjugated linoleic acid. 

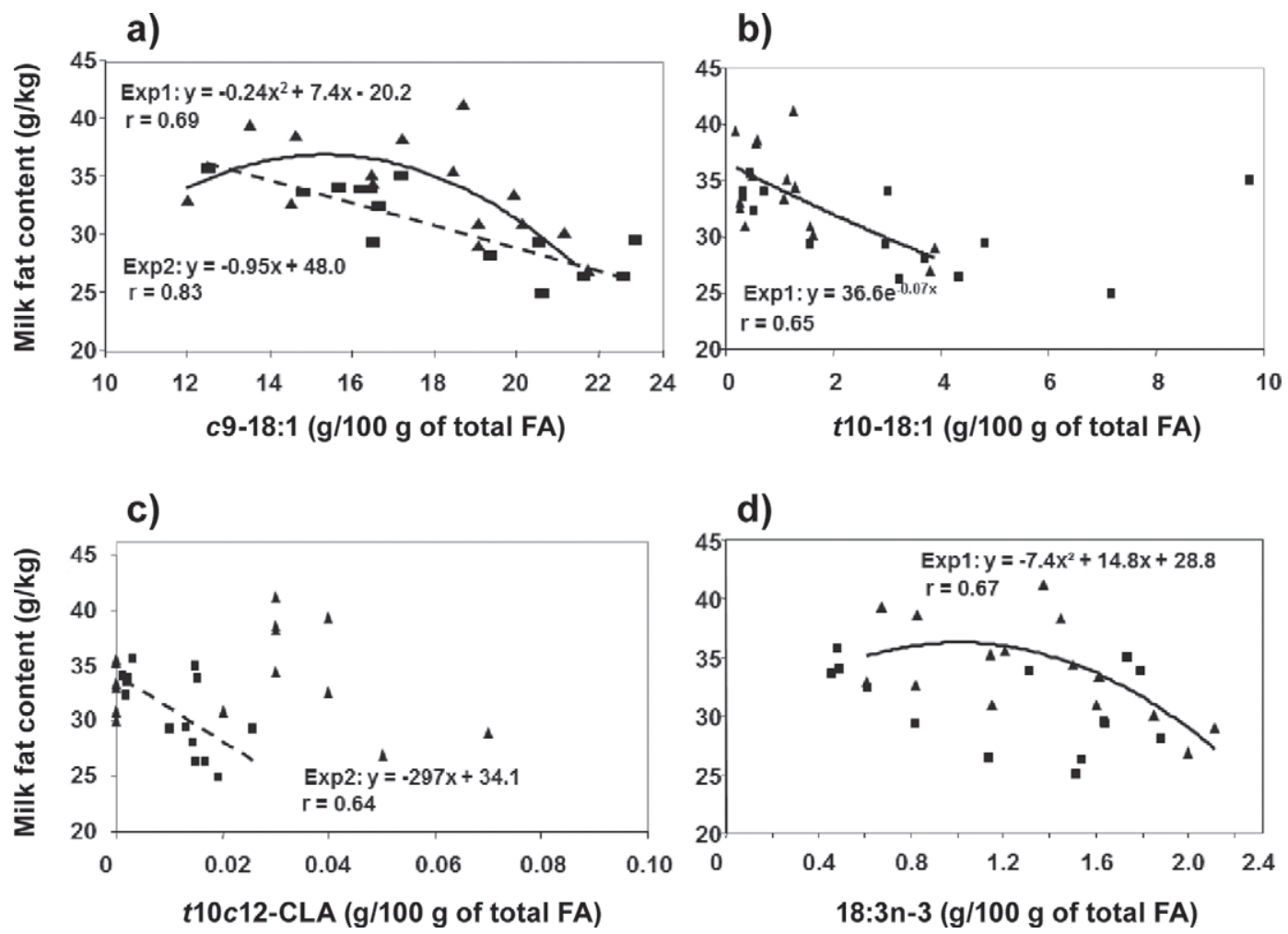

Figure 2. Relationships between milk fat content and selected FA percentages in milks from Holstein cows fed natural grassland hay- [triangles and solid line; experiment $1(\operatorname{Exp} 1) ; \mathrm{n}=15]$ or corn silage-based [squares and dashed line; experiment $2($ Exp2); $\mathrm{n}=14$ ] diets without supplemental extruded linseed or supplemented with extruded linseed at 5, 10, or $15 \%$ of DM. The milk fat content (y; g/kg) can also be predicted by a linear combination of a selected milk FA (x; g/100 g of total FA) and nature of forage (z; hay forage considered as 0$)$. Regression curves within experiment were represented when $P<0.05$. (a) y $=-0.84 \mathrm{x}(P<0.001)-2.6 \mathrm{z}(P<0.05)+51.3(P<0.001) ;(\mathrm{b}) \mathrm{y}=-0.71 \mathrm{x}$ $(P<0.05)-1.8 \mathrm{z}(\mathrm{NS})+36.7(P<0.001) ;(\mathrm{c}) \mathrm{y}=-48.8 \mathrm{x}(\mathrm{NS})-3.7 \mathrm{z}(P<0.05)+38.8(P<0.001) ;(\mathrm{d}) \mathrm{y}=-3.6 \mathrm{x}(P<0.05)-3.5 \mathrm{z}(P<$ $0.05)+42.3(P<0.001) . c=$ cis; $t=$ trans; CLA $=$ conjugated linoleic acid.

linearly $(-24.1 \mathrm{~g} / 100 \mathrm{~g}$ of total FA between $\mathrm{H} 0$ and H15 diets, $P<0.001)$ with increasing amounts of extruded linseed, whereas the milk MUFA $(+19.0 \mathrm{~g} / 100$ $\mathrm{g}$ of FA, $P<0.001)$, PUFA $(+4.85 \mathrm{~g} / 100 \mathrm{~g}$ of FA, $P$ $<0.001)$, and total trans FA $(+14.7 \mathrm{~g} / 100 \mathrm{~g}$ of FA, $P$ $<0.001$ ) contents increased linearly. The total n-3 FA increased linearly $(+1.18 \mathrm{~g} / 100 \mathrm{~g}$ of $\mathrm{FA}, P<0.001)$ and the n-6:n-3 ratio decreased in a linear $(P<0.001)$ manner. The n-6:n-3 ratio decreased from $\mathrm{H} 0$ to $\mathrm{H} 15$ diets, at a greater rate with the $\mathrm{H} 5$ diet (quadratic effect, $P<0.01$ ).

The milk percentages of saturated short-chain FA decreased in a linear manner $(P<0.05$ for $4: 0$ and $P$ $<0.001$ for $6: 0,8: 0$, and $10: 0$ ) by $1.3,1.3,0.9$, and 2.3 $\mathrm{g} / 100 \mathrm{~g}$ of FA for 4:0, 6:0, 8:0, and 10:0, respectively, with $\mathrm{H} 15$ compared with $\mathrm{H} 0$ diets. The milk percentages of saturated medium-chain FA decreased in a quadratic manner $(P<0.05$ for $12: 0$ and 14:0, and $P$ $<0.01$ for 16:0) from 4.24, 13.9, and $30.6 \mathrm{~g} / 100 \mathrm{~g}$ of FA for H0 to $1.87,7.6$, and $15.8 \mathrm{~g} / 100 \mathrm{~g}$ of FA for the H15 diet, with most of the decrease occurring between $\mathrm{H} 0$ and $\mathrm{H} 5$ diets, for 12:0, 14:0, and 16:0, respectively.
The milk percentage of 18:0 increased in a quadratic manner $(P<0.05)$, with most of the increase occurring between $\mathrm{H} 0$ and $\mathrm{H} 5$ diets. Then, it plateaued from $\mathrm{H} 5$ to $\mathrm{H} 15$ diets.

The percentage of cis-9,trans-11 CLA and the sum of CLA increased in a linear $(P<0.05)$ and quadratic $(P$ $<0.05)$ manner, increasing to the highest value for the $\mathrm{H} 10$ diet (1.64 and $1.89 \mathrm{~g} / 100 \mathrm{~g}$ of FA, respectively), and then decreasing to 1.12 and $1.28 \mathrm{~g} / 100 \mathrm{~g}$ of FA between H10 and H15 diets, respectively. The milk percentage of cis-9, cis-11 CLA increased in a quadratic manner $(P$ $<0.05)$, increasing to the highest value for H10 (0.12 $\mathrm{g} / 100 \mathrm{~g}$ of FA), and then decreasing to $0.05 \mathrm{~g} / 100 \mathrm{~g}$ of FA for the H15 diet. The milk cis-9,trans-13 ( $P<$ $0.001)$, trans-11, cis-15 $(P<0.001)$, and cis-9,trans 12 18:2 $(P<0.01)$, and $18: 3 \mathrm{n}-3(P<0.001)$ percentages increased linearly with increasing amounts of extruded linseed. In contrast, the milk 18:2n-6 and total n-6 FA percentages did not differ between the diets. The milk 20:3n-6 $(P<0.001)$ and $20: 4 n-6(P<0.01)$ percentages as well as eicosapentaenoic acid $(P<0.001)$ and docosapentaenoic acid $(22: 5 \mathrm{n}-3 ; P<0.05)$ percentages 
Table 1. Dry matter intake and milk production and composition in Holstein cows fed natural grassland hay $(\mathrm{H})$ diets without supplemental extruded linseed or supplemented with extruded linseed at 5\% (H5), 10\% (H10), or 15\% (H15) of DM (experiment 1)

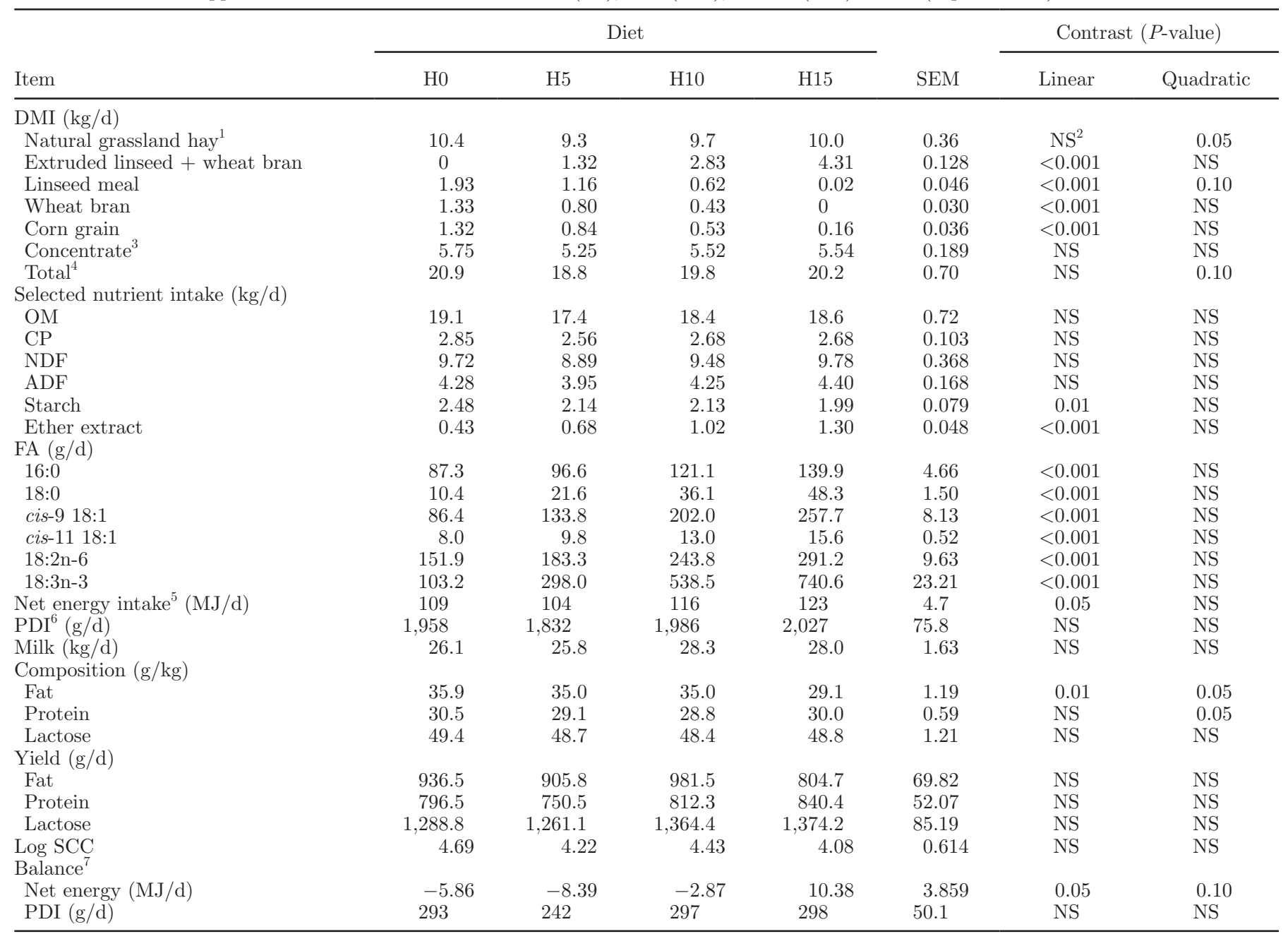

${ }^{1}$ Long-cut natural grassland hay.

${ }^{2} \mathrm{NS}=P>0.10$.

${ }^{3}$ Concentrate $(\mathrm{g} / \mathrm{kg})$ : wheat (200), barley (200), dehydrated sugar beet pulp (310), toasted rapeseed meal (150), soybean meal (87), molassed sugar beet (20), and $\mathrm{MgO}, \mathrm{CaCO}_{3}, \mathrm{CaHPO}_{4}$, and binders (30).

${ }^{4}$ Total DMI plus mineral-vitamin mix. Minerals (\%): P (0.8), Ca (1), Mg (0.5), and Na (0.5). Trace elements (mg/kg): Cu (15). Vitamins (IU/ $\mathrm{kg})$ : vitamin $\mathrm{A}(6,000)$, vitamin $\mathrm{D}_{3}(1,250)$, and vitamin $\mathrm{E}(10 \mathrm{mg} / \mathrm{kg})$.

${ }^{5}$ From Institut National de la Recherche Agronomique (INRA, 2007).

${ }^{6} \mathrm{PDI}=$ protein digestible in the intestines (INRA, 2007).

${ }^{7}$ Balance $=$ intake, maintenance, and production requirements, calculated according to INRA (2007).

decreased linearly with extruded linseed supplementation from $\mathrm{H} 0$ to $\mathrm{H} 15$ diets.

All individual odd- and even-branched-chain FA and odd-linear-chain FA decreased in a linear manner with increasing amounts of extruded linseed (except 7:0, iso 17 , and iso 18). The percentages of 7:0 (quadratic effect, $P<0.01$ ) and 13:0 (quadratic effect, $P<0.05$ ) initially decreased from $\mathrm{H} 0$ to $\mathrm{H} 10$ diets and then increased with the H15 diet. The percentage of iso 15 initially plateaued and then decreased from H5 to H15 diets (quadratic effect, $P<0.05$ ). The percentage of anteiso 17 was higher with the $\mathrm{H} 5$ diet and lower with the $\mathrm{H} 15$ diet (quadratic effect, $P<0.01$ ).

Transfer efficiency from intake to milk for $18: 2 \mathrm{n}-6$ (from 9.9 to $4.4 \%$ for $\mathrm{H} 0$ to $\mathrm{H} 15$ diets, respectively) and 18:3n-3 (from 6.7 to $2.1 \%$ ) decreased linearly $(P<$ 0.001 ) with increasing amounts of extruded linseed in the diet.

The total trans $(+10.8 \mathrm{~g} / 100 \mathrm{~g}$ of FA, $P<0.001)$ and cis $(+9.2 \mathrm{~g} / 100 \mathrm{~g}$ of FA, $P<0.01)$ isomers of 18:1 and the percentages of individual trans and cis isomers of 18:1 increased linearly from H0 to H15 diets (Table 
Table 2. Plasma metabolite concentrations and differences between jugular and mammary venous concentrations of metabolites in Holstein cows fed natural grassland hay $(\mathrm{H})$ diets without supplemental extruded linseed or supplemented with extruded linseed at 5\% (H5), 10\% (H10), or $15 \%$ (H15) of DM (experiment 1)

\begin{tabular}{|c|c|c|c|c|c|c|c|}
\hline Item & \multicolumn{4}{|c|}{ Diet } & SEM & \multicolumn{2}{|c|}{ Contrast ( $P$-value) } \\
\hline \multicolumn{8}{|c|}{ Jugular concentration $(\mathrm{m} M)$} \\
\hline BHBA & 0.343 & 0.318 & 0.280 & 0.197 & 0.0617 & 0.05 & NS \\
\hline Glucose & 3.967 & 3.889 & 4.044 & 4.078 & 0.1293 & NS & NS \\
\hline NEFA & 0.100 & 0.120 & 0.091 & 0.111 & 0.0234 & NS & NS \\
\hline BHBA & 0.154 & 0.126 & 0.113 & 0.028 & 0.0415 & NS & NS \\
\hline Glucose & 0.967 & 0.722 & 0.972 & 0.700 & 0.1249 & NS & NS \\
\hline NEFA & 0.005 & -0.022 & -0.066 & -0.018 & 0.0190 & 0.01 & NS \\
\hline
\end{tabular}

${ }^{1} \mathrm{NS}=P>0.10$.

6). The percentage of the trans-10 isomer increased in a linear $(P<0.001)$ and quadratic $(P<0.05)$ manner, with the highest value for the H15 diet. The percentage of the trans-11 isomer increased in a linear $(P<0.05)$ and quadratic $(P<0.05)$ manner, increasing to the highest value $(5.61 \mathrm{~g} / 100 \mathrm{~g}$ of FA) for the H10 diet, and then decreasing to $3.20 \mathrm{~g} / 100 \mathrm{~g}$ of FA for the H15 diet. The milk cis-12 isomer increased in a linear $(P$ $<0.001)$ and quadratic $(P<0.05)$ manner, with the highest value for the H15 diet and with the highest increase between $\mathrm{H} 0$ and $\mathrm{H} 5$ diets. The milk cis-15 isomer increased in a linear $(P<0.001)$ and quadratic $(P<$ $0.01)$ manner, with the highest value for H15, and with the highest increase between H10 and H15 diets.

Experiment 2. The ranges among treatments in the milk FA composition from this experiment were generally lower than for experiment 1 (Table 7 ). The milk SFA content decreased linearly $(-21.0 \mathrm{~g} / 100 \mathrm{~g}$ of FA, $P<0.01)$ with increasing amounts of extruded linseed, whereas the milk MUFA $(+17.1 \mathrm{~g} / 100 \mathrm{~g}$ of FA, $P<$ $0.01)$, PUFA $(+3.2 \mathrm{~g} / 100 \mathrm{~g}$ of FA, $P<0.001)$, and total trans FA $(+14.8 \mathrm{~g} / 100 \mathrm{~g}$ of FA, $P<0.01)$ contents increased. The total n-6 FA $(P<0.05)$ decreased and n-3 FA $(+1.03 \mathrm{~g} / 100 \mathrm{~g}$ of FA, $P<0.01)$ increased linearly, and the n-6:n-3 ratio decreased in a linear manner $(P$ $<0.001$ ) with increasing amounts of extruded linseed. The n-6:n-3 ratio decreased strongly from CS0 to CS5 diets, and then decreased slightly with the CS15 diet (quadratic effect, $P<0.01$ ).

The milk percentages of saturated short- and medium-chain FA decreased by $0.9,1.2,0.7,1.9$, and 2.0 $\mathrm{g} / 100 \mathrm{~g}$ of FA for 4:0 $(P<0.05), 6: 0,8: 0$, and 10:0 $(P<$ $0.01)$, and 12:0 $(P<0.001)$, respectively, from CS0 to CS15 diets. The milk percentages of 14:0 $(-5.9 \mathrm{~g} / 100$ $\mathrm{g}$ of FA) and 16:0 (-14.9 g/100 g of FA) decreased linearly $(P<0.001)$ from CS0 to CS15 diets. The milk percentage of 18:0 increased linearly $(P<0.05)$ from
CS0 to CS15 diets. The response of cis-9,trans-11 CLA percentage to increasing amounts of extruded linseed was linear $(P<0.01)$. The responses of trans-11,cis-15 18:2 initially increased at a greater rate with the CS5 diet, but then slightly increased with the CS10 and CS15 diets (quadratic effect, $P<0.05$ ). The 20:2n-6 and 20:3n-6 content decreased linearly. The percentage of 20:3n-6 initially decreased from CS0 to CS10 diets and then increased (quadratic effect, $P<0.05$ ). For OBCFA, only iso 14 and 15:0 decreased linearly $(P<$ 0.05) with increasing amounts of linseed, whereas iso 17 increased from CS0 to CS10 diets and then plateaued (linear effect, $P<0.01$, quadratic effect, $P<0.10$ ).

The transfer efficiency from intake to milk for $18: 2 \mathrm{n}-$ 6 (from 6.5 to $3.8 \%, P<0.05$ ) and 18:3n-3 (from 6.2 to $2.1 \%, P<0.001$ ) decreased linearly with increasing amounts of extruded linseed in the diet. The transfer efficiency for 18:3n-3 initially decreased strongly from CS0 to CS5 diets, but then decreased slightly (quadratic effect, $P<0.01)$.

The total trans $(+12.14 \mathrm{~g} / 100 \mathrm{~g}$ of FA, $P<0.01)$ and cis $(+5.94 \mathrm{~g} / 100 \mathrm{~g}$ of $\mathrm{FA}, P<0.01)$ isomers of $18: 1$ and the percentages of individual trans and cis isomers of 18:1 increased linearly from CS0 to CS15 diets (Table 8), except for the trans-10, trans-11, and cis-12 isomers.

Relationships Between Milk FA and Increasing Amounts of 18:3n-3 Intake. The data for the relationships between selected milk FA and 18:3n-3 intake for the 2 experiments are reported in Figure 1. The milk percentage of the sum of 12:0 to 16:0 decreased in a similar manner in the 2 experiments with increasing 18:3n-3 intake. The increases of the milk stearic and oleic acids with increasing 18:3n-3 intake did not differ between the 2 forages $(P>0.10)$. The increase of the total trans 18:1 was slightly higher $(P<0.01)$ for the CS than for the $\mathrm{H}$ diets. The milk trans-10 18:1 increased $(P<0.01)$ more with the CS than with the $\mathrm{H}$ diets in 
Table 3. Dry matter intake and milk production and composition in Holstein cows fed corn silage (CS) diets without supplemental extruded linseed or supplemented with extruded linseed at 5\% (CS5), 10\% (CS10), or 15\% (CS15) of DM (experiment 2)

\begin{tabular}{|c|c|c|c|c|c|c|c|}
\hline \multirow[b]{2}{*}{ Item } & \multicolumn{4}{|c|}{ Diet } & \multirow[b]{2}{*}{ SEM } & \multicolumn{2}{|c|}{ Contrast ( $P$-value $)$} \\
\hline & CS0 & CS5 & CS10 & CS15 & & Linear & Quadratic \\
\hline Natural grassland hay ${ }^{1}$ & 0.84 & 0.74 & 0.77 & 0.80 & 0.032 & $\mathrm{NS}^{2}$ & 0.10 \\
\hline Corn silage & 10.4 & 10.2 & 9.8 & 9.3 & 0.72 & NS & NS \\
\hline Extruded linseed + wheat bran & 0.00 & 1.31 & 2.52 & 3.54 & 0.096 & $<0.001$ & NS \\
\hline Soybean meal & 1.12 & 1.09 & 1.09 & 1.01 & 0.072 & NS & NS \\
\hline Corn grain & 1.13 & 0.73 & 0.32 & 0.00 & 0.079 & 0.001 & NS \\
\hline Concentrate $^{3}$ & 2.26 & 2.10 & 2.15 & 1.94 & 0.172 & NS & NS \\
\hline Total $^{4}$ & 18.7 & 18.2 & 17.7 & 16.7 & 1.19 & NS & NS \\
\hline \multicolumn{8}{|l|}{ Selected nutrient intake $(\mathrm{kg} / \mathrm{d})$} \\
\hline $\mathrm{OM}$ & 17.3 & 16.9 & 16.6 & 15.7 & 1.11 & NS & NS \\
\hline $\mathrm{CP}$ & 2.67 & 2.59 & 2.54 & 2.35 & 0.171 & NS & NS \\
\hline $\mathrm{NDF}$ & 7.63 & 7.53 & 7.52 & 7.29 & 0.496 & NS & NS \\
\hline $18: 0$ & 11.5 & 23.4 & 34.1 & 42.8 & 1.68 & $<0.001$ & NS \\
\hline cis-9 18:1 & 108.7 & 159.6 & 203.8 & 237.6 & 11.32 & $<0.001$ & NS \\
\hline cis-11 18:1 & 7.3 & 10.2 & 12.9 & 14.8 & 0.64 & $<0.001$ & NS \\
\hline $18: 2 n-6$ & 248.2 & 289.2 & 322.2 & 344.1 & 20.90 & 0.05 & NS \\
\hline $18: 3 n-3$ & 69.6 & 276.3 & 463.1 & 621.2 & 21.79 & $<0.001$ & NS \\
\hline Net energy intake $^{5}(\mathrm{MJ} / \mathrm{d})$ & 113 & 115 & 111 & 114 & 7.5 & NS & NS \\
\hline $\operatorname{PDI}^{6}(\mathrm{~g} / \mathrm{d})$ & 1,764 & 1,685 & 1,576 & 1,710 & 112.8 & NS & NS \\
\hline Milk $(\mathrm{kg} / \mathrm{d})$ & 25.3 & 25.2 & 23.6 & 25.1 & 3.71 & NS & NS \\
\hline \multicolumn{8}{|l|}{ Composition (g/kg) } \\
\hline Fat & 33.8 & 30.7 & 27.1 & 31.2 & 1.44 & 0.05 & 0.05 \\
\hline Protein & 30.4 & 28.9 & 29.9 & 30.6 & 1.39 & NS & NS \\
\hline Lactose & 48.7 & 49.0 & 47.0 & 47.4 & 1.41 & NS & NS \\
\hline \multicolumn{8}{|l|}{ Yield (g/d) } \\
\hline
\end{tabular}

${ }^{1}$ Long-cut natural grassland hay. ${ }^{2} \mathrm{NS}=P>0.10$.

${ }^{3}$ Concentrate: $(\mathrm{g} / \mathrm{kg})$ : wheat (200), barley (200), dehydrated sugar beet pulp (310), toasted rapeseed meal (150), soybean meal (87), molassed sugar beet (20), and $\mathrm{MgO}, \mathrm{CaCO}_{3}, \mathrm{CaHPO}_{4}$, and binders (30).

${ }^{4}$ Total DMI plus mineral-vitamin mix. Minerals (\%): P (0.8), Ca (1), Mg (0.5), and Na (0.5). Trace elements (mg/kg): Cu (15). Vitamins (IU/ $\mathrm{kg})$ : vitamin $\mathrm{A}(6,000)$, vitamin $\mathrm{D}_{3}(1,250)$, and vitamin $\mathrm{E}(10 \mathrm{mg} / \mathrm{kg})$.

${ }^{5}$ From Institut National de la Recherche Agronomique (INRA, 2007).

${ }^{6} \mathrm{PDI}=$ protein digestible in the intestines (INRA, 2007).

${ }^{7}$ Balance $=$ intake, maintenance, and production requirements, calculated according to INRA (2007).

response to increasing 18:3n-3 intake. In contrast, the milk trans-11 18:1 percentage tended to increase $(P<$ $0.10)$ more strongly with $\mathrm{H}$ than CS. The response of the milk cis-9,trans-11 CLA to increasing amounts of 18:3n-3 intake tended to be $(P<0.10)$ curvilinear for the $\mathrm{H}$ diets, whereas it tended to increase only slightly for the CS diets. The milk 18:3n-3 percentage increased in a similar logarithmic manner in the 2 experiments.

A PCA was performed to summarize the correlations among the different milk FA percentages and the varia- tion induced by the nature of the forage and increasing amounts of linseed in the diet (Figure 3). The first and second principal components (PC1 and PC2, respectively) described $56.1 \%$ of the total variation. The score plots (Figure 3a) show that the samples from the different animals and periods were mainly distributed according to the decreasing amount of extruded linseed in the diet along the PC1 axis. The PC2 axis separated the observations according to the nature of the forage, with $\mathrm{H}$ in the positive range. Several SFA (6:0, 8:0, 
Table 4. Plasma metabolites and differences between jugular and mammary venous concentrations of metabolites in Holstein cows fed corn silage (CS) diets without supplemental extruded linseed or supplemented with extruded linseed at 5\% (CS5), 10\% (CS10), or 15\% (CS15) of DM (experiment 2)

\begin{tabular}{|c|c|c|c|c|c|c|c|}
\hline Item & \multicolumn{4}{|c|}{ Diet } & SEM & \multicolumn{2}{|c|}{ Contrast ( $P$-value $)$} \\
\hline \multicolumn{8}{|c|}{ Jugular concentration $(\mathrm{m} M)$} \\
\hline BHBA & 0.191 & 0.231 & 0.190 & 0.059 & 0.0460 & 0.01 & 0.05 \\
\hline Glucose & 4.133 & 4.078 & 4.256 & 3.950 & 0.1320 & NS & NS \\
\hline NEFA & 0.184 & 0.264 & 0.263 & 0.239 & 0.0626 & NS & NS \\
\hline Glucose & 0.689 & 0.650 & 0.711 & 0.328 & 0.2263 & NS & NS \\
\hline NEFA & 0.025 & -0.004 & 0.002 & -0.079 & 0.0419 & NS & NS \\
\hline
\end{tabular}

${ }^{1} \mathrm{NS}=P>0.10$.

10:0, 12:0, 14:0, and 16:0), cis-9 10:1, and 20:3n-6 were positively correlated with PC1 (Figure 3b). The cis $(9,13$, and 15$)$ and trans $(6+7+8,12,13+14$, and 16$)$ isomers of $18: 1$; trans- 11 , cis- 15 , cis- 9 ,trans- 12 , and cis9,trans-13 18:2; and 18:3n-3 were negatively correlated with PC1. The milk fat content was positively correlated with $\mathrm{PC} 1$. The trans-11 18:1, cis-9,cis-11 CLA, 20:0, 22:0, 24:0, and 20:5n-3 percentages were positively correlated with PC2, whereas cis-11 and trans-11 16:1, and 20:2n-6 were negatively correlated. The milk samples rich in 10:0, cis-9 10:1, and 12:0 were closely associated with the $\mathrm{H} 0$ diets, whereas milk samples rich in 18:0; trans-11 18:1; and cis-9,trans-11, cis-9,cis-11, and trans-11,trans-13 CLA were associated with the H10 or H15 diets. Milk samples with high trans-10 and cis-11 18:1, and trans-9,trans-12 18:2 contents were essentially associated with the CS10 diet.

The milk trans-10, cis-13, and cis-15 18:1 percentages had the most negative linear correlations (Table 9) with the milk fat content for the H-based diets, whereas the trans-13+14, cis-9, cis-14, and cis-15 18:1; cis-9,trans-13 18:2; and trans-10,cis-12 CLA (Figure 2) percentages had the most negative linear correlations for the CS-based diets (Table 9).

\section{DISCUSSION}

\section{Effects of Linseed Supplementation on Milk Yield and Protein Content}

The effect of extruded linseed supplementation on the milk protein content or yield is inconsistent in the literature. Egger et al. (2007) reported no effect of extruded linseed; in contrast, others reported a marked reduction in the protein content, combined with (Hurtaud et al., 2010) or without (Gonthier et al., 2005; Akraim et al., 2007; Chilliard et al., 2009; Ferlay et al.,
2010) an increase in milk yield. The trend of reduced milk protein content for the $\mathrm{H} 10$ diet in the present trial could be due to a dilution effect on the milk protein, as the milk yield numerically increased for this diet, without a change in total protein output.

\section{Effects of Linseed Supplementation on Milk Fat Content According to the Nature of the Forage}

The milk fat content (and numerically fat yield) decreased with the H-based and CS-based diets supplemented with 15 and $10 \%$ of extruded linseed, respectively. According to the biohydrogenation theory of milk fat depression (Bauman and Griinari, 2000), we speculate that some isomers of $18: 1$ and $18: 2$, and, second, 18:3n-3 are responsible for the reduced milk fat content because the latter was significantly and negatively correlated with these FA. Nevertheless, for each type of forage, we observed that specific FA were correlated with the milk fat content. For the Hbased diets, the trans-10 18:1, trans-11,cis-15 18:2, and 18:3n-3 percentages had the most negative correlations with the milk fat content, as previously reported during long-term supplementation with extruded linseed of grass-based diets (Lerch et al., 2012). In contrast, these FA were not correlated with the milk fat content for the CS-based diets. Increases in milk trans-10 18:1 and trans-11,cis-15 18:2 may have resulted from the ruminal biohydrogenation (RBH) of 18:3n-3 (Shingfield et al., 2010). In particular, trans-10 18:1 could be derived from the reduction of trans-10, cis-15 18:2 during ruminal 18:3n-3 metabolism (Shingfield et al., 2010). For H-based diets, Dangin et al. (2008) observed that ruminal concentration of trans-10 18:1 tended to be increased and that of trans-11,cis-15 18:2 increased with increasing amounts of extruded linseed. Previous studies have also shown that trans-11,cis-15 18:2 was 
Table 5. Percentages of 4- to 24-carbon (not including 18:1 isomers) FA in milk fat from Holstein cows fed natural grassland hay (H) diets without supplemental extruded linseed or supplemented with extruded linseed at 5\% (H5), 10\% (H10), or 15\% (H15) of DM (experiment 1)

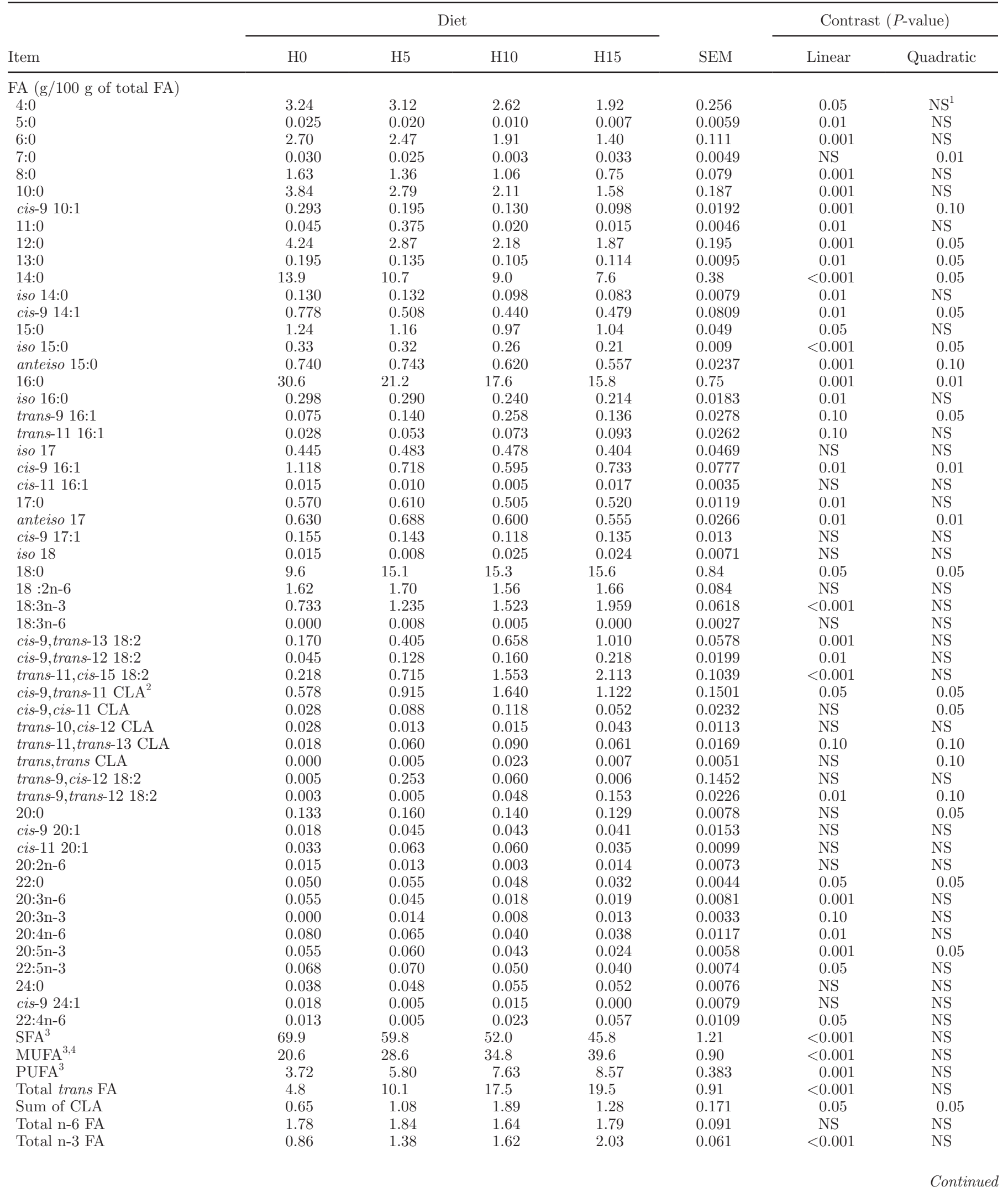


Table 5 (Continued). Percentages of 4- to 24-carbon (not including 18:1 isomers) FA in milk fat from Holstein cows fed natural grassland hay $(\mathrm{H})$ diets without supplemental extruded linseed or supplemented with extruded linseed at 5\% (H5), 10\% (H10), or 15\% (H15) of DM (experiment 1)

\begin{tabular}{|c|c|c|c|c|c|c|c|}
\hline Item & \multicolumn{4}{|c|}{ Diet } & SEM & \multicolumn{2}{|c|}{ Contrast ( $P$-value $)$} \\
\hline $\begin{array}{l}\text { n-6:n-3 } \\
\text { Transfer efficiency }\end{array}$ & 2.08 & 1.34 & 1.01 & 0.90 & 0.079 & $<0.001$ & 0.01 \\
\hline $18: 2 \mathrm{n}-6$ & 9.93 & 8.43 & 6.25 & 4.42 & 0.573 & $<0.001$ & NS \\
\hline $18: 3 n-3$ & 6.67 & 3.79 & 2.77 & 2.09 & 0.394 & $<0.001$ & 0.05 \\
\hline
\end{tabular}

${ }^{1} \mathrm{NS}=P>0.10$.

${ }^{2} \mathrm{CLA}=$ conjugated linoleic acid.

${ }^{3}$ The sum of unidentified peaks was 5.8, 5.85, 5.6, and $6.06 \%$ for H0, H5, H10, and H15 diets, respectively.

${ }^{4}$ The sum of MUFA included all FA having a double bond.

${ }^{5}$ Expressed as FA yield $\times 100 / \mathrm{FA}$ intake.

enhanced in the duodenal digesta in response to $\mathrm{H}-$ based diets containing linseed oil as a source of 18:3n-3 (Loor et al., 2004, 2005b). It is likely that the ruminal trans-10 18:1 inhibited de novo FA synthesis because inhibitory effects of this isomer were observed when infusing amounts at the abomasum corresponding to flows observed in cows receiving oil-rich diets (Shingfield et al., 2010).

The trans-10,cis-12 CLA was negatively correlated with the milk fat content (Figure 2) and sum of 4:0 to $16: 0$ ( $\mathrm{r}=0.76, P<0.05$; data not shown) only for the CS-based diets. The ruminal trans-10, cis-12 CLA content generally increases during diet-induced milk fat depression and is the main hallmark of such diets (Bauman and Griinari, 2003). The trans-10,cis-12 CLA is formed unequivocally during 18:2n-6 RBH (Shingfield et al., 2010), and its concentration in milk increased significantly with the CS-based diets because the 18:2n6 intake was higher for the CS than for $\mathrm{H}$ diets (301 vs. $218 \mathrm{~g} / \mathrm{d}$ ). Nevertheless, the milk fat content was negatively correlated only to the 18:2n- 6 intake for the H-based diets, and not to the milk trans-10,cis-12 CLA (Figure 2).

Dietary conditions such as low NDF or high starch content in the diet could induce a different ruminal environment, resulting in altered pathways of $\mathrm{RBH}$ and producing FA intermediates that are specific for each forage type. The NDF content was relatively high and not very different for the 2 types of diets (average 42 vs. $48 \%$ for CS and $\mathrm{H}$ diets, respectively). The differ-

Table 6. Percentages of 18:1 isomers in milk fat from Holstein cows fed natural grassland hay (H) diets without supplemental extruded linseed or supplemented with extruded linseed at $5 \%$ (H5), $10 \%$ (H10), or 15\% (H15) of DM (experiment 1)

\begin{tabular}{|c|c|c|c|c|c|c|c|}
\hline $\begin{array}{l}\text { FA } \\
(\mathrm{g} / 100 \mathrm{~g} \text { of total FA) }\end{array}$ & \multicolumn{4}{|c|}{ Diet } & SEM & \multicolumn{2}{|c|}{ Contrast ( $P$-value $)$} \\
\hline \multicolumn{8}{|l|}{ trans $18: 1$} \\
\hline 5 & 0.020 & 0.025 & 0.078 & 0.075 & 0.0073 & 0.001 & NS \\
\hline $6+7+8$ & 0.210 & 0.433 & 0.743 & 0.902 & 0.0391 & $<0.001$ & NS \\
\hline 9 & 0.203 & 0.348 & 0.508 & 0.574 & 0.0206 & $<0.001$ & NS \\
\hline 12 & 0.245 & 0.578 & 0.873 & 1.234 & 0.0555 & $<0.001$ & NS \\
\hline $13+14$ & 0.70 & 1.70 & 2.74 & 3.99 & 0.196 & $<0.001$ & NS \\
\hline $16+$ cis- 14 & 0.308 & 0.690 & 1.010 & 1.360 & 0.0688 & 0.001 & NS \\
\hline Total & 3.7 & 7.4 & 12.9 & 14.5 & 0.64 & $<0.001$ & NS \\
\hline \multicolumn{8}{|l|}{ cis $18: 1$} \\
\hline 9 & 13.6 & 18.0 & 18.5 & 21.1 & 0.80 & 0.001 & NS \\
\hline 11 & 0.388 & 0.453 & 0.470 & 0.485 & 0.0167 & 0.01 & NS \\
\hline
\end{tabular}

${ }^{1} \mathrm{NS}=P>0.10$. 
Table 7. Percentages of 4- to 24-carbon (not including 18:1 isomers) FA in milk fat from Holstein cows fed corn silage (CS) diets without supplemental extruded linseed or supplemented with extruded linseed at 5\% (CS5), 10\% (CS10), or 15\% (CS15) of DM (experiment 2)

\begin{tabular}{|c|c|c|c|c|c|c|c|}
\hline Item & \multicolumn{4}{|c|}{ Diet } & SEM & \multicolumn{2}{|c|}{ Contrast ( $P$-value $)$} \\
\hline \multicolumn{8}{|l|}{ FA $(\mathrm{g} / 100 \mathrm{~g}$ of total FA) } \\
\hline $5: 0$ & 0.023 & 0.007 & 0.014 & 0.021 & 0.0034 & NS & 0.05 \\
\hline $6: 0$ & 2.41 & 1.86 & 1.25 & 1.27 & 0.182 & 0.01 & NS \\
\hline $7: 0$ & 0.023 & 0.011 & 0.011 & 0.016 & 0.0034 & NS & 0.10 \\
\hline cis-9 10:1 & 0.25 & 0.15 & 0.08 & 0.07 & 0.016 & 0.001 & 0.01 \\
\hline $11: 0$ & 0.046 & 0.020 & 0.018 & 0.028 & 0.0061 & 0.10 & 0.05 \\
\hline $12: 0$ & 3.79 & 2.67 & 1.80 & 1.78 & 0.213 & 0.001 & 0.05 \\
\hline 13:0 & 0.11 & 0.07 & 0.07 & 0.08 & 0.009 & 0.10 & 0.10 \\
\hline 14:0 & 13.4 & 11.2 & 8.0 & 7.5 & 0.440 & 0.001 & 0.107 \\
\hline iso 14:0 & 0.11 & 0.10 & 0.11 & 0.07 & 0.020 & 0.05 & NS \\
\hline cis-9 14:1 & 0.76 & 0.56 & 0.42 & 0.35 & 0.082 & 0.01 & NS \\
\hline trans-9 16:1 & 0.10 & 0.16 & 0.17 & 0.22 & 0.015 & 0.001 & NS \\
\hline trans-11 16:1 & 0.105 & 0.113 & 0.135 & 0.120 & 0.0136 & NS & NS \\
\hline iso 17 & 0.37 & 0.43 & 0.52 & 0.48 & 0.027 & 0.01 & 0.10 \\
\hline cis-9 16:1 & 1.10 & 0.96 & 0.73 & 0.65 & 0.113 & 0.05 & NS \\
\hline cis-11 16:1 & 0.023 & 0.021 & 0.020 & 0.018 & 0.0039 & NS & NS \\
\hline $17: 0$ & 0.51 & 0.53 & 0.52 & 0.48 & 0.023 & NS & NS \\
\hline anteiso 17 & 0.63 & 0.64 & 0.66 & 0.56 & 0.042 & NS & NS \\
\hline cis-9 17:1 & 0.16 & 0.15 & 0.13 & 0.12 & 0.013 & NS & NS \\
\hline iso 18 & 0.04 & 0.04 & 0.03 & 0.02 & 0.005 & NS & NS \\
\hline 18:0 & 9.1 & 11.5 & 14.5 & 15.5 & 1.58 & 0.05 & NS \\
\hline $18: 2 \mathrm{n}-6$ & 1.89 & 1.76 & 1.94 & 1.67 & 0.074 & NS & NS \\
\hline $18: 3 n-3$ & 0.51 & 1.00 & 1.65 & 1.58 & 0.118 & 0.001 & 0.10 \\
\hline $18: 3 n-6$ & 0.010 & 0.006 & 0.003 & 0.003 & 0.0027 & NS & NS \\
\hline cis-9,trans-13 18:2 & 0.19 & 0.52 & 0.78 & 0.77 & 0.111 & 0.05 & NS \\
\hline $20: 0$ & 0.102 & 0.095 & 0.116 & 0.111 & 0.0088 & NS & NS \\
\hline cis-9 20:1 & 0.058 & 0.055 & 0.055 & 0.053 & 0.0226 & NS & NS \\
\hline cis-11 20:1 & 0.050 & 0.054 & 0.068 & 0.055 & 0.0059 & NS & NS \\
\hline $20: 2 \mathrm{n}-6$ & 0.023 & 0.020 & 0.016 & 0.011 & 0.0016 & 0.01 & NS \\
\hline $22: 0$ & 0.030 & 0.019 & 0.030 & 0.028 & 0.0023 & NS & NS \\
\hline $20: 3 n-6$ & 0.053 & 0.029 & 0.020 & 0.025 & 0.0052 & 0.05 & 0.05 \\
\hline $20: 3 n-3$ & 0.010 & 0.014 & 0.013 & 0.010 & 0.0023 & NS & 0.05 \\
\hline $20: 4 n-6$ & 0.090 & 0.050 & 0.040 & 0.043 & 0.0094 & 0.05 & 0.10 \\
\hline $20: 5 n-3$ & 0.035 & 0.036 & 0.023 & 0.030 & 0.0079 & NS & NS \\
\hline $22: 5 n-3$ & 0.073 & 0.052 & 0.040 & 0.043 & 0.0087 & NS & NS \\
\hline $24: 0$ & 0.015 & 0.008 & 0.020 & 0.010 & 0.0032 & NS & NS \\
\hline cis-9 24:1 & 0.005 & 0.000 & 0.000 & 0.000 & 0.0017 & NS & NS \\
\hline $22: 4 n-6$ & 0.018 & 0.013 & 0.008 & 0.008 & 0.0028 & NS & NS \\
\hline $\mathrm{SFA}^{3}$ & 69.0 & 60.8 & 48.9 & 48.1 & 2.66 & 0.01 & NS \\
\hline MUFA $^{3,4}$ & 22.0 & 28.7 & $\begin{array}{l}40.9 \\
37.9\end{array}$ & $\begin{array}{l}40.1 \\
39.1\end{array}$ & $\begin{array}{l}2.00 \\
2.37\end{array}$ & 0.01 & NS \\
\hline PUFA $^{3}$ & 3.9 & 5.4 & 7.2 & 7.1 & 0.34 & 0.001 & 0.10 \\
\hline Total trans FA & 4.9 & 10.5 & 17.4 & 19.7 & 1.80 & 0.01 & NS \\
\hline Sum of CLA & 0.67 & 0.81 & 0.96 & 1.05 & 0.059 & 0.01 & NS \\
\hline Total n-6 FA & 2.09 & 1.88 & 2.02 & 1.76 & 0.068 & 0.05 & NS \\
\hline Total n-3 FA & 0.63 & 1.09 & 1.72 & 1.66 & 0.127 & 0.01 & 0.10 \\
\hline
\end{tabular}


Table 7 (Continued). Percentages of 4- to 24-carbon (not including 18:1 isomers) FA in milk fat from Holstein cows fed corn silage (CS) diets without supplemental extruded linseed or supplemented with extruded linseed at 5\% (CS5), 10\% (CS10), or 15\% (CS15) of DM (experiment 2)

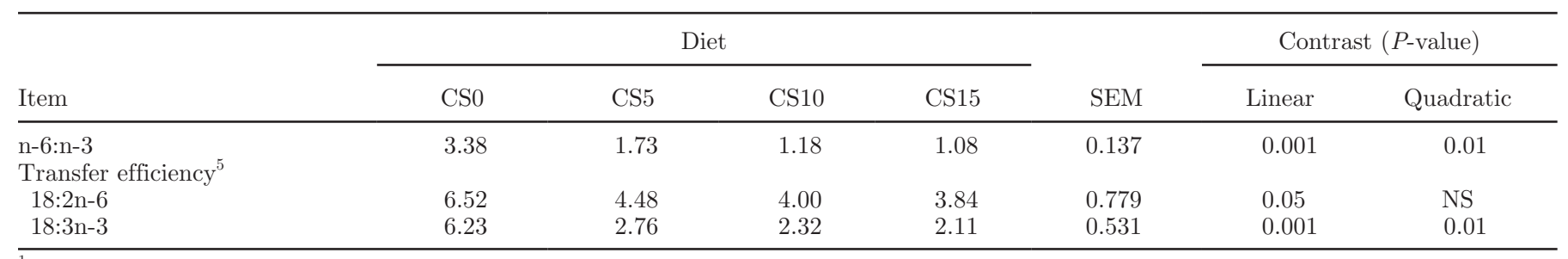

${ }^{1} \mathrm{NS}=P>0.10$

${ }^{2} \mathrm{CLA}=$ conjugated linoleic acid.

${ }^{3}$ The sum of unidentified peaks was $5.1,5.12,6.0$, and $5.76 \%$ for the CS0, CS5, CS10 and CS15 diets, respectively.

${ }^{4}$ The sum of MUFA included all FA having a double bond.

${ }^{5}$ Expressed as FA yield $\times 100 /$ FA intake.

ence in the ruminal production of FA between the 2 forages could be due to the starch level in the diet. It is probable that the higher starch content in CS than $\mathrm{H}$ diets (25 vs. $11 \%$, respectively) could have favored the ruminal production of some intermediates (e.g., trans-10, cis-12 CLA, and trans-12, trans-13+14, and trans-16 + cis-14 18:1) of biohydrogenation that can be implicated in the decreased milk fat content (Shingfield et al., 2010; Lerch et al., 2012).

The decrease in milk fat content could be due partly to a decreased availability of the precursors of milk short- and medium-chain FA. The ruminal acetate and butyrate production may have been decreased with the CS diet supplemented with $15 \%$ extruded linseed, as suggested by the observed lower jugular plasma concentrations and jugular-mammary venous differences for acetate and BHBA. Moreover, the high correla- tion between the jugular-mammary venous difference for the acetate and milk yield of 4:0 to 16:0 in the case of the CS-based diets suggests a putative role for availability of acetate in affecting the milk fat content (Figure 4). Conversely, a decrease in the expression of FA synthesis genes resulting in a lower demand for these nutrients in mammary epithelial cells could be the cause of a decreased gradient for the uptake of these precursors, and subsequently a lower uptake. Decreases in plasma BHBA concentration and in the short- and medium-chain FA percentages have already been reported by Hurtaud et al. (2010) for CS-based diets supplemented with increasing amounts (up to 4\%) of extruded linseed. In contrast, Loor et al. (2005a) reported no change in the plasma acetate and BHBA concentrations with $\mathrm{H}$-based diets supplemented with $3 \%$ linseed oil.

Table 8. Percentages of 18:1 isomers in milk fat from Holstein cows fed corn silage (CS) diets without supplemental extruded linseed or supplemented with extruded linseed at 5\% (CS5), 10\% (CS10), or 15\% (CS15) of DM (experiment 2)

\begin{tabular}{|c|c|c|c|c|c|c|c|}
\hline $\begin{array}{l}\text { FA } \\
(\mathrm{g} / 100 \mathrm{~g} \text { of total FA) }\end{array}$ & \multicolumn{4}{|c|}{ Diet } & SEM & \multicolumn{2}{|c|}{ Contrast ( $P$-value) } \\
\hline \multicolumn{8}{|l|}{ trans $18: 1$} \\
\hline 5 & 0.015 & 0.031 & 0.056 & 0.064 & 0.006 & 0.01 & NS \\
\hline $6+7+8$ & 0.23 & 0.48 & 0.80 & 0.88 & 0.099 & 0.01 & NS \\
\hline 9 & 0.23 & 0.30 & 0.55 & 0.55 & 0.072 & 0.05 & NS \\
\hline $13+14$ & 0.54 & 1.96 & 3.38 & 3.56 & 0.276 & 0.001 & 0.10 \\
\hline $16+c i s-14$ & 0.27 & 0.66 & 1.13 & 1.32 & 0.086 & 0.001 & NS \\
\hline $\begin{array}{l}\text { Total } \\
\text { cis } 18: 1\end{array}$ & 3.6 & 7.9 & 13.6 & 15.7 & 1.65 & 0.01 & NS \\
\hline 9 & 14.9 & 17.4 & 20.5 & 19.7 & 1.18 & 0.01 & NS \\
\hline 11 & 0.46 & 0.50 & 0.56 & 0.63 & 0.031 & 0.05 & NS \\
\hline
\end{tabular}

${ }^{1} \mathrm{NS}=P>0.10$. 
a)

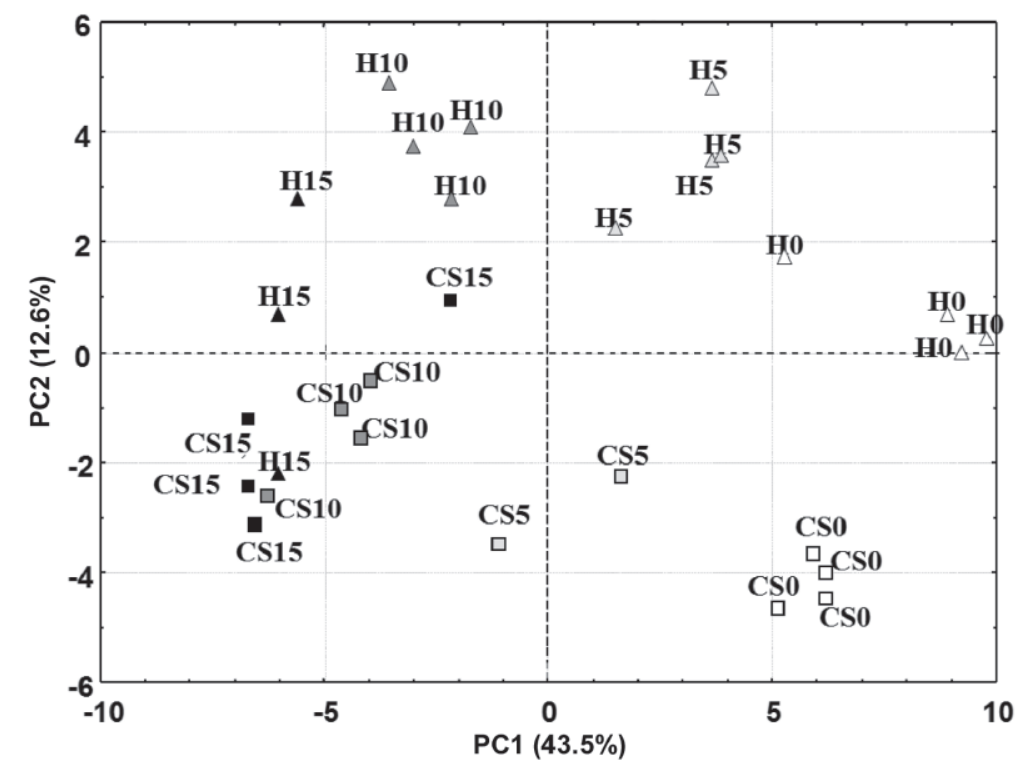

b)

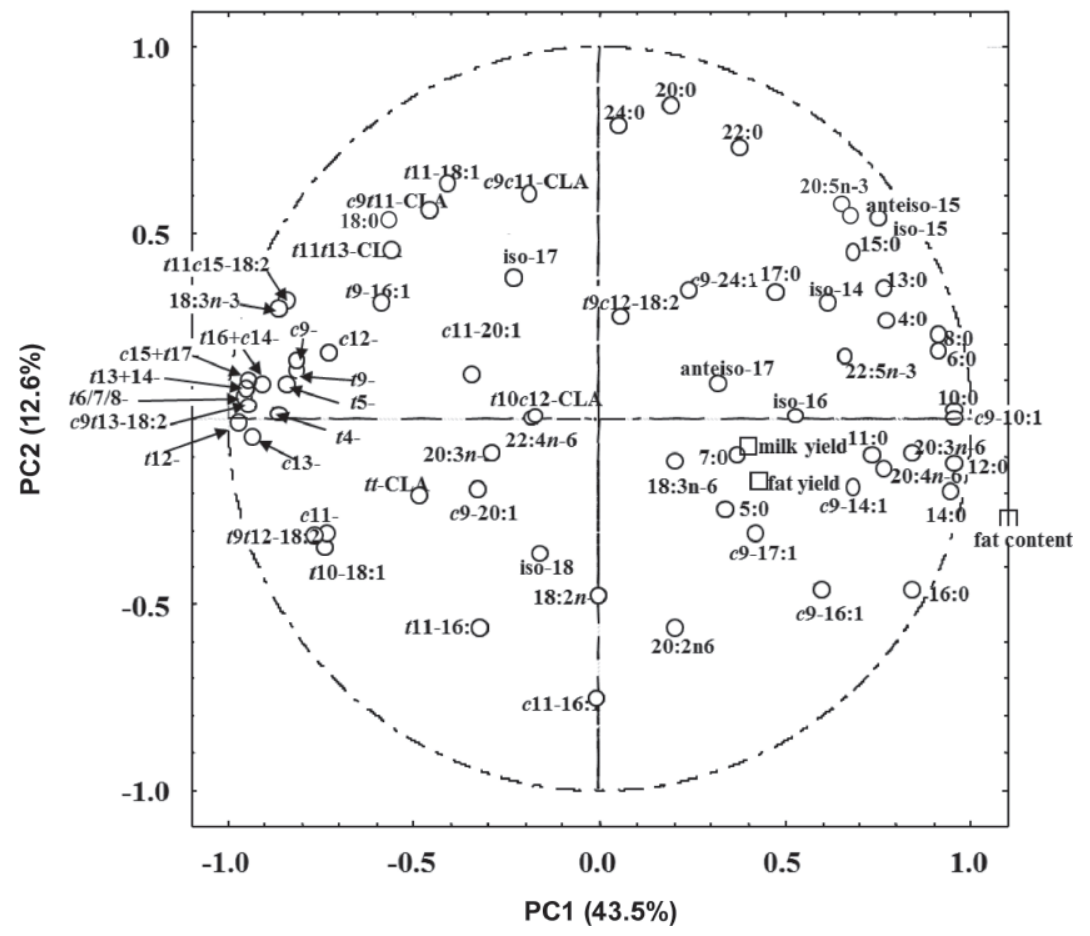

Figure 3. Results of a principal components (PC) analysis based on milk yield, fat content and yield, and milk FA composition (4:0; 5:0; 6:0; 7:0; 8:0; 10:0; cis-9 10:1; 11:0; 12:0; 13:0; iso 14; 14:0; iso 15 ; anteiso 15 ; cis-9 14:1; 15:0; iso 16; 16:0; iso 17; trans-9 16:1; anteiso 17; trans-11 16:1; cis-9 16:1; cis-11 16:1; 17:0, iso 18; cis-9 17:1; 18:0; trans-4, trans-5, trans-6+7+8, trans-9, trans-10, trans-11, trans-12, trans-13-, trans-16 + cis-14, cis-9, cis-11, cis-12, cis-13, and cis-15 + trans-17 18:1; trans-9,trans-12, cis-9,trans-13, cis-9,trans-12, trans-9, cis-12, and trans-11,cis-15 18:2; 18:2n-6; 20:0; 18:3n-6; cis-9 20:1; cis-11 20:1; 18:3n-3; cis-9,trans-11, trans-10,cis-12, cis-9, cis-11, trans-11,trans-13, and trans,trans conjugated linoleic acid; 20:2n-6; 22:0; 20:3n-6; 20:3n-3; 20:4n-6; 24:0; 20:5n-3; cis-9 24:1; 22:4n-6; and 22:5n-3) presented as follows. (a) A score plot of 29 milks (15 observations from experiment 1 and 14 observations from experiment 2) with increasing amounts of extruded linseed in the diet $(0,5,10$, and $15 \%)$ and with 2 forages [natural grassland hay (H; triangles) vs. corn silage (CS; squares)]. The colors used were white, light gray, dark gray, and black for diets supplemented without and with extruded linseed at 5, 10, or 15\%, respectively. (b) A loading plot of the different variables projected on the first 2 PC (PC1 and PC2). In experiment 1, Holstein cows were fed natural grassland H diets without (H0) supplemental extruded linseed or supplemented with extruded linseed at 5\% (H5), 10\% (H10), or 15\% (H15) of DM. In experiment 2, Holstein cows were fed CS diets without (CS0) supplemental extruded linseed or supplemented with extruded linseed at 5\% (CS5), 10\% (CS10), or 15\% (CS15) of DM. $c=$ cis; $t=$ trans; CLA $=$ conjugated linoleic acid. 


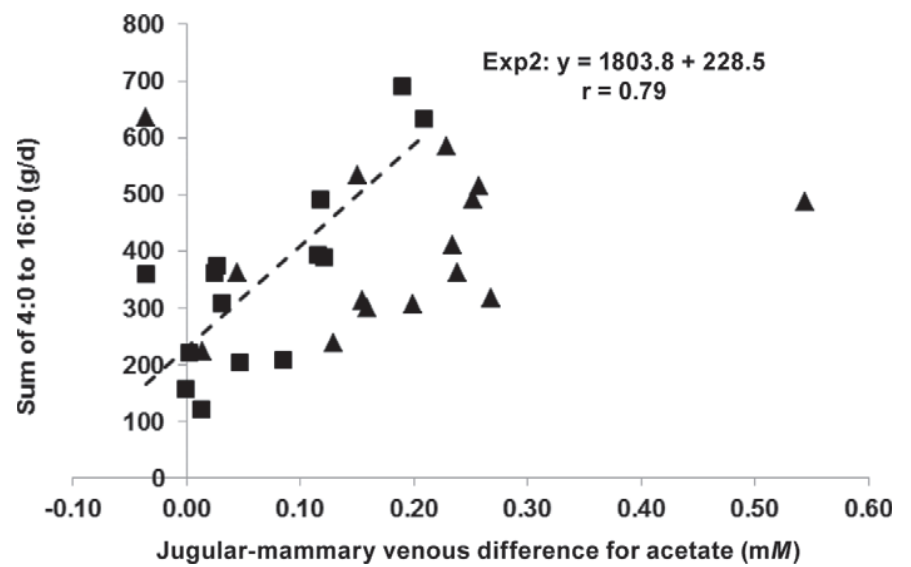

Figure 4. Relationships between milk SFA secretion (sum of 4:0 to 16:0) and acetate jugular-mammary venous difference from Holstein cows fed natural grassland hay- (triangles and solid line; experiment $1 ; \mathrm{n}=15)$ or corn silage-based [squares and dashed line; experiment $2(\operatorname{Exp} 2) ; \mathrm{n}=14]$ diets without supplemental extruded linseed or supplemented with extruded linseed at 5,10 , or $15 \%$ of DM.

\section{Effect of Linseed Supplementation on Milk FA Composition According to the Nature of the Forage}

The decrease in the milk SFA content with extruded linseed supplementation was similar between the $\mathrm{H}$ and CS diets (reductions of 24 and $21 \mathrm{~g} / 100 \mathrm{~g}$ of total FA between the control diet and diet supplemented with 15\% linseed, respectively; Figure 1). This decrease is similar to that $(-22 \mathrm{~g} / 100 \mathrm{~g})$ reported by Chilliard et al. (2009) with $21 \%$ extruded linseed added to a CSbased diet. In contrast, the decrease is larger than that $(-11 \mathrm{~g} / 100 \mathrm{~g})$ reported by Kennelly and Khorasani (1992) with $15 \%$ whole linseed added to an alfalfa/ grass silage-based diet. The different effects possibly could be due to the faster rate of oil release into the rumen from extruded seeds than from whole seeds, which could result in the higher production of trans $\mathrm{FA}$ in the rumen and, thus, an inhibitory effect on de novo mammary lipogenesis (Chilliard et al., 2009). Dilution of SFA by increased 18:1 FA derived from FA supplied by the extruded linseed likely contributed a portion of the decrease in SFA.

Linseed supplementation increased the milk percentages of cis and trans isomers of 18:1. These percentages increased almost linearly in the following order: cis-9 $>$ trans $-13+14>$ trans $-10>$ trans $-11>$ trans $-16 /$ cis -14 $>$ trans-12 for the H-based diets. These results are in agreement with Lerch et al. (2012) for conserved grassbased diets with high starch content. We observed the following order: cis-9 $>$ trans-10 $>$ trans $-13+14>$ trans-11 > trans-16/cis-14 > trans-12 for the CS-based diets, in agreement with Chilliard et al. (2009) and Hurtaud et al. (2010), also for CS-based diets.

Extruded linseed supplementation of the CS-based diets only slightly enhanced the milk cis-9,trans-11 CLA $(+0.31 \mathrm{~g} / 100 \mathrm{~g}$ of total FA from the CS0 to the CS15 diets) concentration, as previously reported by Chilliard et al. (2009) and Hurtaud et al. (2010). This result is most likely because this type of diet did not lead to production mainly of trans-11 18:1, and then cis-9,trans-11 CLA (Shingfield et al., 2010), but rather to large amounts of trans-10 18:1 when the amount of extruded linseed was increased in the diet (Figure 1). In contrast, extruded linseed supplementation to the H-based diets increased the milk cis-9,trans-11 CLA content $(+1.64 \mathrm{~g} / 100 \mathrm{~g}$ of total FA for the H10 diet), a

Table 9. Correlations among the percentages of selected milk FA and milk fat content for experiments 1 and 2

\begin{tabular}{|c|c|c|c|c|c|c|}
\hline \multirow{2}{*}{$\begin{array}{l}\text { FA } \\
(\mathrm{g} / 100 \mathrm{~g} \text { of total FA) }\end{array}$} & \multicolumn{2}{|c|}{$\begin{array}{l}\text { Experiment } 1, \\
\text { hay-based diet }^{1}\end{array}$} & \multicolumn{2}{|c|}{$\begin{array}{c}\text { Experiment } 2, \\
\text { corn silage-based } \text { diet }^{2}\end{array}$} & \multicolumn{2}{|c|}{ All experiments ${ }^{3}$} \\
\hline & $\mathrm{r}$ & $P$-value & $\mathrm{r}$ & $P$-value & $\mathrm{r}$ & $P$-value \\
\hline trans-4 18:1 & -0.54 & 0.05 & -0.50 & 0.10 & -0.50 & 0.01 \\
\hline trans $-6+7+818: 1$ & -0.47 & 0.10 & -0.49 & 0.10 & -0.48 & 0.01 \\
\hline trans-9 18:1 & -0.46 & 0.10 & -0.46 & 0.10 & -0.46 & 0.05 \\
\hline trans-10 18:1 & -0.62 & 0.05 & & $\mathrm{NS}$ & -0.48 & 0.01 \\
\hline trans-12 18:1 & -0.53 & 0.05 & -0.58 & 0.05 & -0.57 & 0.001 \\
\hline trans $-13+14$ 18:1 & -0.54 & 0.05 & -0.66 & 0.01 & -0.58 & 0.001 \\
\hline trans-16 + cis-14 18:1 & -0.54 & 0.05 & -0.62 & 0.05 & -0.55 & 0.01 \\
\hline cis-13 18:1 & -0.60 & 0.05 & -0.58 & 0.05 & -0.58 & 0.001 \\
\hline cis-15 18:1 & -0.67 & 0.01 & -0.60 & 0.05 & -0.56 & 0.01 \\
\hline cis-9,trans-13 18:2 & -0.56 & 0.05 & -0.68 & 0.01 & -0.59 & 0.001 \\
\hline trans-11,cis-15 18:2 & -0.45 & 0.10 & & $\mathrm{NS}$ & & NS \\
\hline C18:3n-3 & -0.56 & 0.05 & & NS & -0.39 & 0.05 \\
\hline trans-10, cis-12 $\mathrm{CLA}^{4}$ & & NS & -0.65 & 0.05 & & NS \\
\hline
\end{tabular}

${ }^{1} \mathrm{n}=15$.

${ }^{2} \mathrm{n}=14$.

${ }^{3} \mathrm{n}=29$.

${ }^{4} \mathrm{CLA}=$ conjugated linoleic acid. 
level that is similar to that observed in cows consuming a mainly semi-mountain permanent grassland pasture ( $80 \%$ of the diet; Ferlay et al., 2008).

Concerning the milk 18:3n-3 concentration, our value for the CS diet supplemented with $15 \%$ extruded linseed was higher than those reported by Chilliard et al. (2009) using 21\% extruded linseed, Gonthier et al. (2005) using $12.7 \%$ extruded linseed, and Hurtaud et al. (2010) using 4\% extruded linseed with CS-based diets. Moreover, the milk 18:3n-3 concentration from the extruded linseed-fed cows in the present experiment (1.0-2.0\%) was higher than that in the milk from pasture-fed cows (0.8 vs. 0.9\%; Ferlay et al., 2008). Nevertheless, the total trans FA content was lower than $7.0 \%$ in the milks from pasture-fed cows (Ferlay et al., 2008), whereas the value was 10.0 to $20.0 \%$ in the milk from cows receiving extruded linseed in the present experiments (Tables 5 and 7). According to the putative role of these FA in CVD (Givens, 2010), the consumption of milk from grazing cows with a lower content of trans FA could be more favorable to human health than that of milk from cows fed winter diets supplemented with linseed. Milk from cows fed H-based diets supplemented with $15 \%$ linseed, compared with the other 7 diets presented in the current paper (and in particular, the CS-based diets), was characterized by a low $\mathrm{n}-6$ :n-3 ratio $(<1)$, as recommended by Legrand et al. (2010) for the whole diet in human nutrition (but with a concomitant increase in the trans FA level).

The PCA shows that the milk 15:0, iso 15, and anteiso 15 percentages could be associated with the control $\mathrm{H}$ diet, and with the $\mathrm{H} 5$ diet. This finding is in agreement with Vlaeminck et al. (2006), who indicated that milk iso 15 increased when CS was replaced by grass silage, or with Ferlay et al. (2008) who reported high correlations between these FA and the proportion of permanent grassland forages in the diet. These data confirm the contribution of cellulolytic bacteria in the ruminal production of these OBCFA (Vlaeminck et al., 2006).

Supplementation with extruded linseed had a higher negative effect on OBCFA (except iso 17) with the H(except the H5 diet) than with the CS-based diets. One explanation could be linked to the higher 18:3n-3 intake with the $\mathrm{H}$ diets than the CS diets, because the severity of a putative inhibitory effect on rumen bacteria that are responsible for the ruminal synthesis of OBCFA is higher with increasing unsaturation of long-chain FA (18:3n-3 vs. 18:2n-6; Vlaeminck et al., 2006). Accordingly, the growth of cellulolytic bacteria could be more reduced than is that of amylolytic bacteria (Vlaeminck et al., 2006). The transfer efficiency for $18: 2 \mathrm{n}-6$ and 18:3n-3 from the feed to milk decreased linearly with intake of the corresponding FA (Figure 5), regardless a)

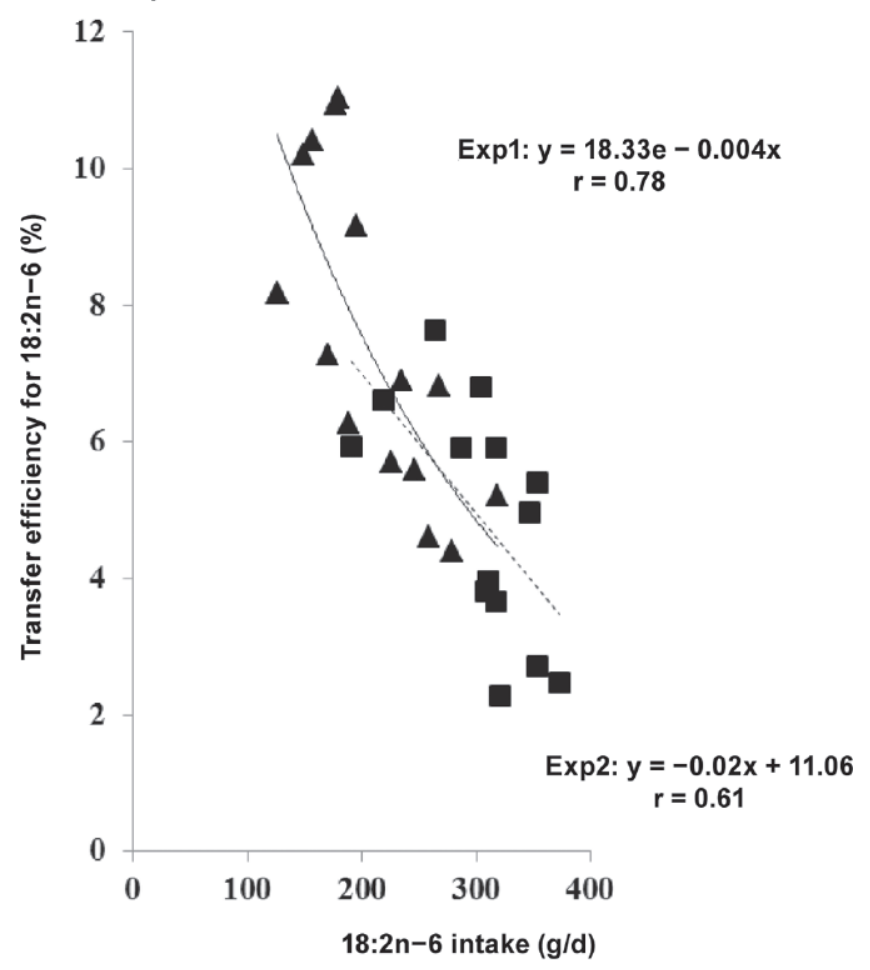

b)

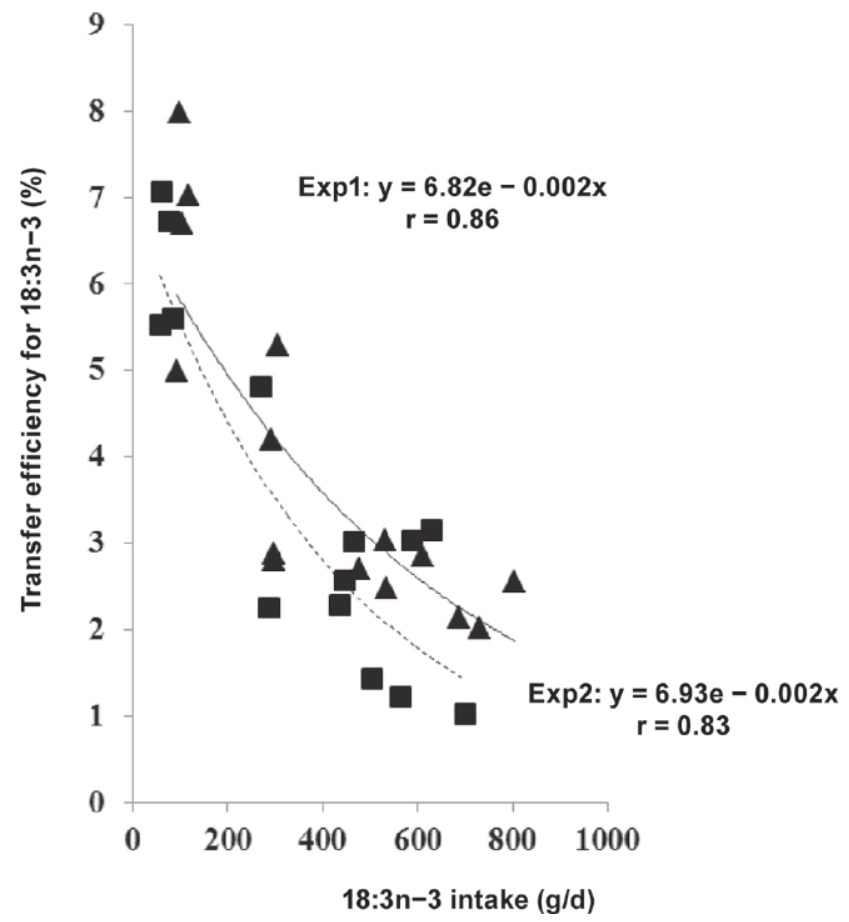

Figure 5. Relationships between $18: 2 \mathrm{n}-6$ or $18: 3 \mathrm{n}-3$ intake and transfer efficiency from the feed to milk for $18: 2 \mathrm{n}-6$ or $18: 3 \mathrm{n}-3$ from Holstein cows fed natural grassland hay- [triangles and solid line; experiment 1 (Exp1); $\mathrm{n}=15$ ] or corn silage-based [squares and dashed line; experiment $2(\operatorname{Exp} 2) ; \mathrm{n}=14]$ diets without supplemental extruded linseed or supplemented with extruded linseed at 5, 10, or $15 \%$ of DM. 
of the forage, as reported by Larsen et al. (2012) with increasing amounts of a linseed:rapeseed mixture.

\section{CONCLUSIONS}

This study with 2 separate trials that had different forages allows indirect comparison of the effects of increasing amounts of extruded linseed according to the nature of the forage on milk FA composition. Feeding up to $15 \%$ of DMI as extruded linseed decreased the milk fat content. The changes in the milk FA composition were different between diets, with an 18:1 isomer footprint specific for each forage type. We concluded that the milk FA composition can be improved by extruded linseed supplementation to increase the potentially beneficial supply of oleic acid, 18:3n-3, cis9,trans-11 CLA, and OBCFA to the human diet, with a concomitant decrease in SFA (in particular, 12:0, 14:0, and 16:0). The extruded linseed supplementation increased the trans FA content (particularly trans-10 18:1 with CS-based diets).

\section{ACKNOWLEDGMENTS}

The authors acknowledge the assistance of S. Rudel, Dominique Roux, F. Anglard, and the team of Les Cèdres Experimental Unit (UMRH, INRA, Theix) for feeding, milking, blood sampling, and caring for the cows, and M. Dangin, P. Capitan, and M. Tourret (UMRH, INRA, Theix) for help in the laboratory analyses. This work was performed with the financial support of the French National Research Agency (Paris, France) under the "Programme National de Recherche en Alimentation et Nutrition Humaine" [project ANR05-PNRA-017-04, entitled Transqual ( Trans fatty acids from dairy sources: A comparison of the biological effect compared to trans fatty acids of technological origin)].

\section{REFERENCES}

Akraim, F., M. C. Nicot, P. Juaneda, and F. Enjalbert. 2007. Conjugated linolenic acid (CLnA), conjugated linoleic acid (CLA), and other biohydrogenation intermediates in plasma and milk fat of cows fed raw or extruded linseed. Animal 1:835-843.

AOAC International. 1997. Official Methods of Analysis. 16th ed. AOAC International, Gaithersburg, MD.

Bauman, D. E., and J. M. Griinari. 2000. Regulation and nutritional manipulation of milk fat. Low-fat milk syndrome. Adv. Exp. Med. Biol. 480:209-216.

Bauman, D. E., and J. M. Griinari. 2003. Nutritional regulation of milk fat synthesis. Annu. Rev. Nutr. 23:203-227.

Brashear, A., and G. A. Cook. 1983. A spectrophotometric, enzymatic assay for D-3-hydroxybutyrate that is not dependent on hydrazine. Anal. Biochem. 131:478-482.

Chardigny, J. M., F. Destaillats, C. Malpuech-Brugère, J. Moulin, D. E. Bauman, A. L. Lock, D. M. Barbano, R. P. Mensink, J. B Bezelgues, P. Chaumont, N. Combe, I. Cristiani, F. Joffre, J. B. German, F. Dionisi, Y. Boirie, and J. L. Sébédio. 2008. Do trans fatty acids from industrially produced sources and from natural sources have the same effect on cardiovascular diseases risk factors in healthy subjects? Results of the trans Fatty Acids Collaboration (TRANSFACT) study. Am. J. Clin. Nutr. 87:558-566.

Chilliard, Y., and A. Ferlay. 2004. Dietary lipids and forages interactions on cow and goat milk fatty acid composition and sensory properties. Reprod. Nutr. Dev. 44:467-492.

Chilliard, Y., F. Glasser, A. Ferlay, L. Bernard, J. Rouel, and M. Doreau. 2007. Diet, rumen biohydrogenation, cow and goat milk fat nutritional quality: A review. Eur. J. Lipid Sci. Technol. 109:828-855.

Chilliard, Y., C. Martin, J. Rouel, and M. Doreau. 2009. Milk fatty acids in dairy cows fed whole crude linseed, extruded linseed, or linseed oil, and their relationship with methane output. J. Dairy Sci. 92:5199-5211.

Dangin, M., F. Glasser, C. Martin, A. Ferlay, Y. Chilliard, and M. Doreau. 2008. Ruminal kinetics of fatty acids and biohydrogenation processes are affected by the amount of extruded linseeds ingested by dairy cows. Page 28 in Proc. Br. Soc. Anim. Sci. Annual Conference. Br. Soc.Anim. Sci., Penicuik, UK.

Deaville, R., D. I. Givens, and J. S. Blacke. 2004. Dietary supplements of whole linseed and vitamin $\mathrm{E}$ to increase levels of $\alpha$-linolenic acid and vitamin $\mathrm{E}$ in bovine milk. Anim. Res. 53:3-12.

Doreau, M., D. Bauchart, and Y. Chilliard. 2011. Enhancing fatty acid composition of milk and meat through animal feeding. Anim. Prod. Sci. 51:19-29.

Egger, P., G. Holzer, S. Segato, E. Werth, F. Schwienbacher, G. Peratoner, I. Andrighetto, and A. Kasal. 2007. Effects of oilseed supplements on milk production and quality in dairy cows fed a hay-based diet. Ital. J. Anim. Sci. 6:395-405.

Ferlay, A., C. Agabriel, C. Sibra, C. Journal, B. Martin, and Y. Chilliard. 2008. Tanker milk variability of fatty acids according to farm feeding and husbandry practices in a French semi-mountain area. Dairy Sci. Technol. 88:193-215.

Ferlay, A., B. Martin, S. Lerch, M. Gobert, P. Pradel, and Y. Chilliard. 2010. Effects of supplementation of maize silage diets with extruded linseed, vitamin $\mathrm{E}$ and plant extracts rich in polyphenols, and morning vs. evening milking on milk fatty acid profiles in Holstein and Montbéliarde cows. Animal 4:627-640.

Givens, D. I. 2010. Milk and meat in our diet: Good or bad for health? Animal 4:1941-1952.

Glasser, F., A. Ferlay, and Y. Chilliard. 2008. Oilseed lipid supplements and fatty acid composition of cow milk: A meta-analysis. J. Dairy Sci. 91:4687-4703.

Gonthier, C., A. F. Mustafa, D. R. Ouellet, P. Y. Chouinard, R. Berthiaume, and H. V. Petit. 2005. Feeding micronized and extruded flaxseed to dairy cows: Effects on blood parameters and milk fatty acid composition. J. Dairy Sci. 88:748-756.

Hurtaud, C., F. Faucon, S. Couvreur, and J. L. Peyraud. 2010. Linear relationship between increasing amounts of extruded linseed in dairy cow diet and milk fatty acid composition and butter properties. J. Dairy Sci. 93:1429-1443.

INRA (Institut National de la Recherche Agronomique). 2007. Alimentation des bovins, ovins et caprins. Besoins des animaux - Valeur des aliments-Tables INRA 2007. Editions Quae, Versailles, France.

Kennelly, J. J., and G. R. Khorasani. 1992. Influence of flaxseed feeding on fatty acid composition of cows' milk. Pages 99-105 in Proceedings of the 54th the Flax Institute Conf., North Dakota State University, Fargo. J. F. Carter, ed. North Dakota State University, Fargo.

Larsen, M. K., L. Hymøller, D. B. Brask-Pedersen, and M. R. Weisbjerg. 2012. Milk fatty acid composition and production performance of Danish Holstein and Danish Jersey cows fed different amounts of linseed and rapeseed. J. Dairy Sci. 95:3569-3578.

Legrand, P., P.-O. Astorg, P. Bougnoux, J. Calvarin, S. Chalon, J. Dallongeville, C. Dumas, P. Friocourt, M. Gerber, P. Guesnet, E. Kalonji, A. Lapillonne, A. Morise, J.-M. Lecerf, I. Margaritis, P. Moulin, and G. Pieroni. 2010. Avis de l'Agence française de sécurité sanitaire des aliments relatif à l'actualisation des apports nutritionnels conseillés pour les acides gras. Afssa, saisine 
n²006-SA-0359. Accessed Mar. 24, 2011. http://www.afssa.fr/ Documents/NUT2006sa0359.pdf.

Lerch, S., A. Ferlay, K. J. Shingfield, B. Martin, D. Pomiès, and Y. Chilliard. 2012. Rapeseed or linseed supplements in grass-based diets: Effects on milk fatty acid composition of Holstein cows over two consecutive lactations. J. Dairy Sci. 95:5221-5241.

Loor, J. J., A. Ferlay, A. Ollier, M. Doreau, and Y. Chilliard. 2005a. Relationship among trans and conjugated fatty acids and bovine milk fat yield due to dietary concentrate and linseed oil. J. Dairy Sci. 88:726-740.

Loor, J. J., K. Ueda, A. Ferlay, Y. Chilliard, and M. Doreau. 2004. Biohydrogenation, duodenal flow, and intestinal digestibility of trans fatty acids and conjugated linoleic acids (CLA), in response to dietary forage:concentrate ratio and linseed oil in dairy cows. J. Dairy Sci. 87:2472-2485.

Loor, J. J., K. Ueda, A. Ferlay, Y. Chilliard, and M. Doreau. 2005b. Intestinal flow and digestibility of trans fatty acids and conjugated linoleic acids (CLA) in dairy cows fed a high-concentrate diet supplemented with fish oil, linseed oil, and sunflower oil. Anim. Feed Sci. Technol. 119:203-225.

Motard-Bélanger, A., A. Charest, G. Grenier, P. Paquin, Y. Chouinard, S. Lemieux, P. Couture, and B. Lamarche. 2008. Study of the effect of trans fatty acids from ruminants on blood lipids and other risk factors for cardiovascular disease. Am. J. Clin. Nutr. 87:593-599.

Petit, H. V. 2010. Review: Feed intake, milk production and milk composition of dairy cows fed flaxseed. Can. J. Anim. Sci. 90:115-127.
Roy, A., J. M. Chardigny, D. Bauchart, A. Ferlay, S. Lorenz, D. Durand, D. Gruffat, Y. Faulconnier, J. L. Sébédio, and Y. Chilliard. 2007. Butters rich either in trans-10-C18:1 or in trans-11-C18:1 plus cis-9, trans-11 CLA differentially affect plasma lipids and aortic fatty streak in experimental atherosclerosis in rabbits. Animal 1:467-476.

Shingfield, K. J., L. Bernard, C. Leroux, and Y. Chilliard. 2010. Role of trans fatty acids in the nutritional regulation of mammary lipogenesis in ruminants. Animal 4:1140-1166.

Shingfield, K. J., Y. Chilliard, V. Toivonen, P. Kairenius, and D. I. Givens. 2008. Trans fatty acids and bioactive lipids in ruminant milk. Adv. Exp. Med. Biol. 606:3-65.

SAS Institute. 2003. SAS/STAT User's Guide. Version 9.1. SAS Institute Inc., Cary, NC.

Sukhija, P. S., and D. L. Palmquist. 1988. Rapid method for determination of total fatty acid content and composition of feedstuffs and feces. J. Agric. Food Chem. 36:1202-1206

Van Soest, P. J., J. B. Robertson, and B. A. Lewis. 1991. Methods for dietary fiber, neutral detergent fiber, and nonstarch polysaccharides in relation to animal nutrition. J. Dairy Sci. 74:3583-3597.

Veissier, I. 1999. Expérimentation animale: Biologie, éthique, réglementation. INRA Prod. Anim. 12:365-375.

Vlaeminck, B., V. Fievez, A. R. J. Cabrita, A. J. M. Fonseca, and R. J. Dewhurst. 2006. Factors affecting odd- and branched-chain fatty acids in milk: A review. Anim. Feed Sci. Technol. 131:389-417. 